\title{
5. A különleges jogrend fejlődése Magyarországon a kilencedik Alaptörvény-módosítás tükrében
}

\section{HORVÁTH ATTILA}

\section{Az Alaptörvény és a különleges jogrend}

A 2012. január 1-jén hatályba lépő Alaptörvény egyik legmarkánsabb újítása a különleges jogrend újraszabályozása volt. A tárgykör új alapokra helyezése - formai szempontból - egyrészt terminológiai változásokat hozott, másrészt érintette a különleges jogrendi szabályok alaptörvényi elhelyezkedését, harmadrészt pedig jelentősen módosult ezen rendelkezések súlya. Az Alaptörvény természetesen tartalmi változásokat is hozott, bár ezek közel sem voltak olyan látványosak, mint a formai újítások. ${ }^{1}$ A következókben ezeket a módosításokat vesszük számba. (Tekintve, hogy a különleges jogrendre irányuló alkotmányos szabályozás számos korábbi elemzés tárgya volt már, nem az egyes különleges jogrendek átfogó bemutatására vállalkozunk, hanem a változásokat kívánjuk felvázolni.)

I Az Alkotmány és az Alaptörvény különleges jogrendi rendelkezéseinek összevetésére lásd például: László, 2018.

Dr. Horváth Attila, $\mathrm{PhD}$

attila.horvath@mfi.gov.hu

vezetô kutató (Mádl Ferenc Összehasonlító Jogi Intézet)

adjunktus (Nemzeti Közszolgálati Egyetem Âllamtudományi és Nemzetközi Tanulmányok Kar, Alkotmányjogi és Összehasonlító Közjogi Tanszék)

Horváth, A. (2021) 'A különleges jogrend fejlődése Magyarországon a kilencedik Alaptörvény-módosítás tükrében' in Nagy, Z., Horváth, A. (szerk.) A különleges jogrend és nemzeti szabályozási modelljei, 122-148. o. Budapest: Mádl Ferenc Összehasonlító Jogi Intézet.

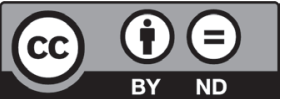




\subsection{Az Alaptörvény formai és szerkezeti újításai}

Az Alkotmányhoz képest az Alaptörvény különleges jogrendi szabályozása formai és szerkezeti szempontból három újdonságot hozott: megváltozott az elnevezés, az elhelyezkedés és a terjedelem.

Ami az elnevezést illeti, az Alaptörvény egy kicsi, de jogértelmezési-dogmatikai szempontól fontos adósságot törlesztett azzal, hogy bevezette a különleges jogrend kifejezést, ezzel egységes terminológiai keretet adva a szabályozási tárgykörnek. Az Alaptörvény előtt ugyanis nem volt egy jogszabályilag definiált összefoglaló elnevezése ezeknek a helyzeteknek. A minősitett időszak terminus technicust ugyan az Alkotmány nem tartalmazta, a jogirodalom és a jogszabályok egy része is használta - és részben ma is használja - ezt a kifejezést. ${ }^{2}$ (Az, hogy mintegy 20 hatályos jogszabályban ${ }^{3}$ a mai napig megtalálható ez a fordulat, abból a szempontból problémás, hogy álláspontunk szerint nem egyértelmú, hogy a kifejezés alatt pontosan mely különleges jogrendi kategóriákat kell érteni - ti. az összeset, vagy csak az Alkotmány által anno elismert kategóriákat.) A különleges jogrend elnevezéssel kapcsolatban a 2020-as tapasztalatok alapján kijelenthető, hogy a kifejezés nem igazán ment át a köztudatba/köznyelvbe, és nemcsak a média, de még a hivatalos állami kommunikáció is valamiért a rendkivüli jogrend kifejezést részesíti előnyben. ${ }^{4}$ Ennek talán az lehet az oka, hogy az utóbbi összetétel kifejezőbb, azaz a laikusok számára is beszédesebb, ugyanis a jelenkori helyzetet jobban megvilágítja a rendkivüli jelző, mint a - teljesen más köznapi jelentéssel bíró - különleges jelző. ${ }^{5}$

Alapvetően változott meg a különleges jogrendi szabályok elhelyezkedése is. Amint az előző fejezetben láttuk, az Alkotmány kissé esetleges módon, szétszórtan, az Ország-

2 A minősitett időszak kifejezésen kívül előfordultak még a következők is: rendkívüli jogrend, különleges állapotok, minősített helyzetek (Szilvásy, 2019, 105. o.). A következőkben az Alkotmány szabályozásának értékelése során is a különleges jogrend kifejezést használjuk.

3 Lásd például:

— a földmérési és térképészeti tevékenységről szóló 2012. évi XLVI. törvény 6. \$ (15) bekezdését;

— az elektronikus hírközlésről szóló 2003. évi C. törvény 86. \$ (1) bekezdés d) pontját; a 92. \$ (9)-(10) bekezdését;

— a nemzeti vérkészlettel való gazdálkodás szabályairól szóló 439/2015. (XII. 28.) Korm. rendelet 8. \$-át;

- az elektronikus hírközlés veszélyhelyzeti és minősített időszaki felkészítésének rendszeréről, az államigazgatási szervek feladatairól, múködésük feltételeinek biztosításáról szóló 100/2004. (IV. 27.) Korm. rendelet egészét.

Az is megjegyzendő, hogy a minősített időszak kifejezést kimondottan ritkán definiálták a jogszabályok. Így például a postáról szóló - már hatálytalan - 2003. évi CI. törvény 3. \$15. pontja értelmében „[m]inősített időszak: az az időszak, amely az Alkotmány alapján rendkívüli állapotnak, szükségállapotnak vagy veszélyhelyzetnek minősül". Ezt az értelmező rendelkezést az Alaptörvény hatálybalépését követően módosították, azonban a minősitett időszak kifejezés továbbra is megmaradt a törvényben.

4 Beszédes tény, hogy a Google internetes kereső a különleges jogrend kifejezésre 32 ezer, a rendkívüli jogrendre pedig több mint háromszor ennyi, 141 ezer találatot ad.

5 Ugyanakkor itt arra is kell utalni, hogy a hipotetikus rendkivüli jogrend kifejezés könnyen összekeverhető (lenne) a rendkivüli állapot kifejezéssel. 
gyưlésrôl (rendkívüli állapot, szükségállapot, váratlan támadás), illetve a Kormányról szóló fejezetben (veszélyhelyzet) szabályozta az egyes különleges jogrendi állapotokat. A rendelkezések nagyobb része - több alkotmánymódosítás nyomán - az Országgyűlés jogköreiről és az országgyűlési képviselőkről szóló szakaszok közé ékelődött be, egyfajta idegen testként funkcionálva, ugyanis az egyes különleges jogrendi időszakok túlmutattak az Országgyứlésen. A szabályozás áttekinthetőségét az is rontotta, hogy az ugyanazon különleges jogrendre vonatkozó rendelkezések sem egy helyen kerültek szabályozásra. ${ }^{6}$ Az Alkotmány nem túl szerencsés szerkezeti megoldásával szemben az Alaptörvény egy különálló részt - tehát nem csak fejezetet! - szentel a különleges jogrendnek, ami annak fényében különösen beszédes, hogy az Alaptörvény - a Nemzeti hitvalláson és a Záró rendelkezéseken kívül - mindössze négy részből áll. Ezzel kapcsolatban Kádár Pál „profiltisztítást” említ, hozzátéve, hogy „[a]z 1949. évi XX. törvény a rendszerváltást követően kialakított minősített időszakokra vonatkozó rendelkezéseit az Alaptörvény immár »fajtatiszta« különleges jogrendi rendelkezésekké nemesítette".?

Rátérve a terjedelemre, az Alkotmányhoz képest az Alaptörvényben a különleges jogrend nagyobb súlyt kapott: az alkotmányozó a korábbinál közel másfélszer nagyobb terjedelemben kodifikálta ezen rendelkezéseket, ezzel az Alaptörvényben a különleges jogrendi szabályok abszolút és relatív súlya is nőtt.

\subsection{Az Alaptörvény tartalmi újításai}

Bár a fenti formai és szerkezeti újítások kétségkívül látványosak, az Alaptörvény tartalmi szempontból nem hozott fundamentális változásokat. Egyrészt az öt különleges jogrend mindegyike megtalálható volt az Alkotmányban (noha - amint arra később visszatérünk - a váratlan támadás nem volt nevesítve), ${ }^{8}$ másrészt a kihirdetések feltételeiben és az egyes szereplők kompetenciájában sem történt igazán jelentős változás.

A rendkívüli állapotra vonatkozó szabályozás minimális mértékben módosult. Az Alaptörvény egyrészt pontosította a kihirdetés egyik feltételét: az Alkotmány hadiállapot esetén tette lehetővé a rendkívüli állapot kihirdetését, ${ }^{9}$ míg az Alaptörvényben már a „, hadiállapot kinyilvánítása" kifejezés szerepel..$^{10}$ Másrészt pontosításra kerültek az Országgyülés megbíza-

6 Így például a megelőző védelmi helyzet meghatározására az Országgyűlés jogköreiről szóló felsorolásban került sor $[19 . \$(3)$ bekezdés $n$ ) pont], de a Kormány cselekvési lehetőségét a Kormányról szóló rendelkezések között találtuk [35. $\$$ (1) bekezdés $m$ ) pont, illetve (3) bekezdés].

7 Kádár, 2014, 1. o.

8 Vö.: Alaptörvény záró és vegyes rendelkezéseinek 23. pontja. Az eredetileg a Magyarország Alaptörvényének átmeneti rendelkezései 25. cikkében megjelenő rendelkezések arra szolgáltak, hogy tisztázzák az Alkotmány egyes különleges jogrendjeinek a „jogutódlását” abban a - nem túl valószínủ - esetben, ha az Alaptörvény hatálybalépése úgy következne be, hogy valamelyik különleges jogrend már korábban ki lett hirdetve.

9 Alkotmány 19. $\$(3)$ bekezdés $h$ ) pont.

10 Alaptörvény 48. cikk (1) bekezdés $a$ ) pont. 
tásával összefüggő rendelkezések. ${ }^{11}$ Ezzel kapcsolatban az Alaptörvénybe az is bekerült, hogy a feloszlott vagy feloszlatott Országgyúlést rendkívüli állapot idején a Honvédelmi Tanács is összehívhatja. ${ }^{12}$ (Az Alkotmány ezt a jogot csak a köztársasági elnöknek adta meg. ${ }^{13}$ )

Ennél fontosabb fejlemény volt, hogy az Alaptörvény pontosabban elhatárolta egymástól a szükségállapot és a veszélyhelyzet kihirdetésének feltételeit. Erre azért volt szükség, mert a két különleges jogrend részben átfedésben volt egymással. ${ }^{14} \mathrm{Az}$ Alkotmány - többek között „az élet- és vagyonbiztonságot tömeges méretekben veszélyeztető [...] elemi csapás vagy ipari szerencsétlenség" esetén tette lehetôvé a szükségállapot kihirdetését, ${ }^{15}$ míg a veszélyhelyzet bevezetésének célja „az élet- és vagyonbiztonságot veszélyeztető elemi csapás, illetőleg következményeinek az elhárítása" volt. ${ }^{16} \mathrm{~A}$ két meghatározás mindegyike utal az (élet- és vagyonbiztonságot veszélyeztető) elemi csapásra, és ebből a szempontból az elhatárolás alapja - elvileg - az lehetett, hogy az élet- és vagyonbiztonságot tömeges méretekben veszélyezteti-e a kialakult helyzet. ${ }^{17} \mathrm{Az}$ Alaptörvény annyiban tisztább szabályozást teremtett, hogy az elemi csapást és az ipari szerencsétlenséget mint tényállási elemeket kivette a szükségállapotból, és ezek immár a veszélyhelyzetről szóló cikkben kerültek szabályozásra. További változás, hogy a Magyar Honvédség felhasználhatósága rendelkezés ${ }^{18}$ átkerült a Magyar Honvédségre vonatkozó rendelkezések közül a szükségállapot szabályai közéi azzal a kiegészítéssel, hogy a „ha a rendőrség alkalmazása nem elegendő" fordulat helyébe a „ha a rendőrség és a nemzetbiztonsági szolgálatok alkalmazása nem elegendő" szövegrész lépett. Az értelmezési problémákat elkerülendő, az Alaptörvény már nem használja a szükséghelyzet kifejezést. Az Alkotmány ezzel a kifejezéssel a szükségállapot kihirdetését megalapozó körülményeket illette (ti. szükséghelyzetben kellett szükségállapotot kihirdetni),, ${ }^{20}$ azonban álláspontunk

11 Alkotmány 28/A. $\$(1)-(2)$ bekezdés vs. Alaptörvény 48. cikk (7) bekezdés.

12 Alaptörvény 48. cikk (8) bekezdés.

13 Alkotmány 28/A. \$ (3) bekezdés.

14 Kádár, 2014, 1. o.

15 Alkotmány 19. $\$(3)$ bekezdés i) pont.

16 Alkotmány 35. \$(1) bekezdés i) pont.

17 A helyzetet némileg árnyalta, hogy az Alkotmány idején hatályos, a polgári védelemről szóló 1996. évi XXXVII. törvény a veszélyhelyzetet a következóképp definiálta: „a szükséghelyzetet [Alkotmány 19. \$ (3) bek. i) pont] el nem érő mértékü, az élet- és vagyonbiztonságot vagy a környezetet veszélyeztető természeti csapás, illetőleg ipari baleset okozta állapot, amelyet különösen a következő események válthatnak ki: [...]”. Tehát a törvény - szemben az Alkotmánnyal - ipari baleset esetén is lehetővé tette veszélyhelyzet bevezetését. Ezzel magyarázható, hogy a 2010. októberi kolontári vörösiszap-katasztrófát követően „csak” veszélyhelyzet kihirdetésére került sor. Ezzel összefüggésben egyes szerzők olyan politikai gyakorlatról írnak, amely „a kihirdethető korabeli minősített időszakok közül az enyhébbek bevezetésére törekedett akár egyes tényállási elemek alkotmányos hiányában is” (Farkas-Till, 2016,65 . o.). Kissé sarkosabb az a vélemény, amely szerint a vörösiszap-katasztrófa kezelése „az Alkotmány szövegszerủ követelményétől eltérve" zajlott le a veszélyhelyzet szabályai szerint [Till, 2019, (23)]. Utóbbi meglátással kapcsolatban kiemelendő, hogy az ipari szerencsétlenség fordulat az Alkotmány akkor hatályos szövegében csak a szükségállapotnál [19. \$(3) bekezdés i) pont] szerepelt, a veszélyhelyzetnél [35. \$ (1) bekezdés i) pont] nem.

18 Alkotmány 40/A. $\$(2)$ bekezdés.

19 Alaptörvény 50. cikk (1) bekezdés.

20 Alkotmány 19. $\$(3)$ bekezdés i) pont. 
szerint ez indokolatlan fogalmi túlbonyolítás volt. ${ }^{21} \mathrm{~A}$ szükségállapotra vonatkozó szabályok közül az Alaptörvény törölte a rendkívüli állapot szubszidiárius jellegére utaló rendelkezést: „A szükségállapotra egyébként a rendkívüli állapotra vonatkozó szabályokat kell alkalmazni." ${ }^{\prime 2}$ Ehelyett külön cikkben foglalta össze a rendkívüli állapotra és a szükségállapotra vonatkozó közös szabályokat, ${ }^{23}$ megkönnyítve ezzel a jogértelmezést.

A megelőző védelmi helyzetre vonatkozó szabályozás egy szempontból került kiegészítésre: az alkotmányozó rögzítette, hogy a Kormány rendelete a megelőző védelmi helyzet megszúnésével hatályát veszti. ${ }^{24}$

A váratlan támadásnál formai szempontból fontos újítás, hogy az Alaptörvény adott egy egzakt megnevezést ennek a helyzetnek, ugyanis az Alkotmány nem tartalmazta a váratlan támadás kifejezést, noha az ezt az állapotot szabályozó rendelkezése ${ }^{25}$ tartalmilag lényegében egybeesett az Alaptörvény későbbi rendelkezésével. ${ }^{26}$ Ahogyan a megelőző védelmi helyzetnél, úgy az Alaptörvény itt is tisztázta, hogy a Kormány rendelete a váratlan támadás megszúnésével hatályát veszti. ${ }^{27}$ Ezen túl kisebb jelentőségú változás, hogy míg az Alkotmány a Kormány intézkedési kötelezettségét kifejezetten a köztársasági elnök által jóváhagyott védelmi terv keretében tette lehetővé, ${ }^{28}$ addig az Alaptörvény úgy fogalmaz, hogy a Kormány „szükség esetén a köztársasági elnök által jóváhagyott fegyveres védelmi terv szerint" teszi meg ezeket az intézkedéseket. ${ }^{29}$

A veszélyhelyzetet illetően - amint arra fentebb utaltunk - fontos változás volt a szükségállapottól való pontosabb elhatárolás, amely eredményeként az elemi csapás és az ipari szerencsétlenség már egyértelmủen a veszélyhelyzet kihirdetését alapozhatja meg. Az Alkotmány a Kormány veszélyhelyzeti intézkedéseivel kapcsolatban még hivatkozott a közrend és a közbiztonság védelmére, azonban az Alaptörvényben már csak a következmények elhárítására utal. A közrend és a közbiztonság védelmére történő utalás tehát kikerült, ami öszszefügghet a szükségállapot és veszélyhelyzet - már említett - „finomhangolásával”, amely

21 Annyiban azonban van létjogosultsága a szükséghelyzet/szükségállapot megkülönböztetésnek, hogy az előbbi a különleges jogrendet megalapozó körülményekre, az utóbbi pedig már a kihirdetett különleges jogrendre vonatkozik. Ezzel kapcsolatban Till úgy vélekedik, hogy „[e]gy ideális szabályozási rend elkülönítené a helyzeteket - amelyek a kiváltó okok tényállásszerú megvalósulásai - az állapotoktól, amelyek a feljogosított állami szerv döntésétől kezdődően a különleges jogrendi időszakra vonatkozó szabályok érvényesítései” [Till, 2019, (13)].

22 Alkotmány 19/C. $\$(5)$ bekezdés.

23 Alaptörvény 48. cikk.

24 Alaptörvény 51. cikk (5) bekezdés.

25 Alkotmány 19/E. \$. Az, hogy az Alkotmány nem adott nevet ennek a különleges jogrendnek, ahhoz a meglehetôsen suta megoldáshoz vezetett, hogy a tulajdonképpeni váratlan támadást a jogszabályok „az Alkotmány 19/E. \$-a szerinti eset"-ként emlegették.

26 Alaptörvény 52 . cikk.

27 Alaptörvény 52. $\$$ (4) bekezdés.

28 Alkotmány 19/E. $\$(1)$ bekezdés.

29 Alaptörvény 52. \$ (1) bekezdés. Megjegyzendő, hogy 2023. július 1-től az Alaptörvény már nem utal a fegyveres védelmi tervre. 
következtében a veszélyhelyzet esetköre a katasztrófa típusú helyzetekre korlátozódott. ${ }^{30}$ (De úgy is lehet érvelni, hogy a következmények elhárításába beleértendő a közrend és a közbiztonság védelme is. (31 $^{31}$ A Alkotmány nem szabályozta a Kormány veszélyhelyzeti rendeleteinek a sorsát; ${ }^{32}$ a hiányosságot pótolandó az Alaptörvény kimondja, hogy ezek a rendeletek 15 napig maradnak hatályban, kivéve, ha a Kormány - az Országgyűlés felhatalmazása alapján - a rendelet hatályát meghosszabbítja..$^{33}$ Ezenfelül az Alaptörvénybe az is bekerült, hogy a Kormány rendelete a veszélyhelyzet megszúnésével hatályát veszti. ${ }^{34}$

Az egyes különleges jogrendek szabályozási változását követően arra is rá kell mutatni, hogy az Alkotmányhoz képest az Alaptörvény jóval szúkebben vonta meg azon alapvető jogok körét, amelyek különleges jogrend idején sem függeszthetők fel vagy korlátozhatók. Az Alkotmány mintegy tucat alapjogot részesített ilyen fokú védelemben, többek között a vallásszabadságot és a szociális biztonsághoz való jogot is. ${ }^{35}$ Az Alaptörvény értelmében viszont ez a feltétel nélküli védelem csak az élethez és emberi méltósághoz való jogot, az emberi méltósághoz való joghoz kapcsolódó nevesített tilalmakat (kínzás, embertelen, megalázó bánásmód és büntetés tilalma stb.), valamint a tisztességes eljáráshoz való jog egyes garanciáit (ártatlanság vélelme, védelemhez való jog, nullum crimen/nulla poena sine lege elve, ne bis in idem elve) illeti meg. ${ }^{66}$ Álláspontunk szerint az Alaptörvény szabályozása észszerűbbnek tûnik, hiszen az Alkotmány olyan alapjogokat is feltétlen védelemben részesített, amelyek korlátozása reális lehetőség lehet egyes különleges jogrendi időszakokban (mint például a személyi szabadság vagy a vallási szertartások megtartása mint a vallásszabadság egyik részjogosítványa). Másrészt arra is rá kell mutatni, hogy az Alkotmány nem az összes különleges jogrend esetén tette lehetôvé az alapjogok korlátozását, hanem csak rendkívüli állapotban, szükségállapotban és veszélyhelyzetben. Az Alaptörvény megoldása ebből a szempontból is logikusabbnak túnik, ugyanis adott esetben például a megelőző védelmi helyzet is szükségessé teheti az alapvetô jogok korlátozását vagy felfüggesztését. ${ }^{37}$

Az Alaptörvény az Alkotmányhoz képest néhány többletgaranciát is tartalmaz a különleges jogrendi rendelkezései között. Az Alkotmány csak a rendkívüli állapot vonatkozásában írta elő, hogy a Honvédelmi Tanács sem jogosult az Alkotmány alkalmazásának felfüggesz-

30 László, 2018, 381-382. 0.

31 Különösen, ha figyelembe vesszük, hogy a katasztrófavédelemről és a hozzá kapcsolódó egyes törvények módosításáról szóló 2011. évi CXXVIII. törvény (Kat.) V. fejezete több olyan intézkedést tesz lehetővé a Kormány számára, amelyeknek van közrend- és közbiztonság-védelmi vonatkozása is (például kijárási tilalom, gyülekezési tilalom, szabad mozgás korlátozása).

32 Így például a kolontári vörösiszap-katasztrófa miatt kihirdetett veszélyhelyzet - ahogyan az a következő fejezetből is kiderül - 267 napig volt hatályban.

33 Alaptörvény 53. \$(3) bekezdés.

34 Alaptörvény 53. \$(4) bekezdés.

35 Jakab, 2011, 301. o.

36 Alaptörvény 54. cikk (1) bekezdés.

37 Vö.: Jakab, 2011, 301. o. 
tésére, ${ }^{38}$ valamint hogy az Alkotmánybíróság múködése nem korlátozható. ${ }^{39}$ (Bár ehhez hozzátehetjük, hogy - amint már utaltam rá - a szükségállapotra egyébként a rendkívüli állapotra vonatkozó szabályokat is alkalmazni kellett, így az előbbi elốrások a szükségállapotra is vonatkoztak.) Az Alaptörvény ezeket a tilalmakat valamennyi különleges jogrendre kiterjeszti. ${ }^{40} \mathrm{Azt}$ is meg kell jegyezni, hogy míg az Alkotmány nem tartalmazott rendelkezéseket a különleges jogrend megszüntetéséról, addig az Alaptörvény kifejezetten kimondja, hogy a különleges jogrendet a különleges jogrend bevezetésére jogosult szerv megszünteti, ha kihirdetésének feltételei már nem állnak fenn. ${ }^{41}$

Összességében tehát elmondható, hogy az Alaptörvény a formai-szerkezeti újítások mellett jobbára valóban csak az Alkotmány szabályozásának rendszerezési és dogmatikai pontosítási igényú újraalkotására vállalkozott. ${ }^{42}$

\subsection{A terrorveszélyhelyzet mint új különleges jogrendi kategória}

Az igazi „innovációt” a 2016-os hatodik Alaptörvény-módosítással beiktatott terrorveszélyhelyzet jelentette, amely a hatodik különleges jogrendként került az Alaptörvénybe.43 Az alkotmányozó olyan új típusú biztonsági kihívásokra hivatkozott, „amelyek a korábbi klasszikus államközi fenyegetésekre adott különleges jogrendi válaszokkal hatékonyan és a szükségesség-arányosság követelményeit betartva megfelelően nem kezelhetők" ${ }^{44} \mathrm{Mindez}$ tehát azt jelentette, hogy - legalábbis az alkotmányozó álláspontja szerint - a terrorizmus nem volt beilleszthető a meglevő különleges jogrendi rendszerbe, így szükség volt egy új különleges jogrendi kategória bevezetésére. A terrorveszélyhelyzet alkotmányos rangra emelésének indokoltságával kapcsolatban eltérnek egymástól a szakmai álláspontok. ${ }^{45}$ Simicskó István úgy érvel, hogy a terrorveszélyhelyzet alaptörvényi beiktatása egy szükséges lépés volt, hiszen egyik különleges jogrendi kategória sem volt alkalmas a terrorveszély kezelé-

38 Alkotmány 19/B. \$ (4) bekezdés.

39 Alkotmány 19/B. $\$(6)$ bekezdés.

40 Alaptörvény 54. $\$(2)$ bekezdés.

41 Alaptörvény 54. cikk (3) bekezdés.

42 Jakab-Till, 2019, 435. o.

43 Alaptörvény 51/A. cikk.

$44 \mathrm{Az}$ Alaptörvény hatodik módosításához füzött indokolás.

45 Megjegyzendő, hogy az ellenzék részéről volt egy alaptörvény-módosítási javaslat, amely a terrorveszély kezelését újabb különleges jogrend bevezetése nélkül kívánta megoldani. A javaslat a Magyar Honvédségre vonatkozó alaptörvényi rendelkezéseket kiegészítette volna azzal, hogy „[a] Magyar Honvédség közreműködhet a rendőrségnek a terrorcselekmény megelőzése, félbeszakítása, következményeinek elhárítása és az elkövetők elfogása érdekében végrehajtott, sarkalatos törvényben meghatározott kiemelt biztonsági intézkedések végrehajtásában". A javaslat indokolása szerint indokolatlan egy újabb különleges jogrendi kategória bevezetése (T/11024. sz. iromány). Elérhető: www.parlament.hu/irom40/11024/11024.pdf (Letöltve: 2020. december 3.). A kormánypárti és az ellenzéki javaslatok összevetésére lásd: Till, 2016, 33-40. o. 
sére..$^{46} \mathrm{Amint}$ kifejti, a rendkívüli állapot a hagyományos, államok közötti háborúra irányuló kategória, ráadásul az állampolgárok jogainak korlátozását terrorveszély esetén a biztonsági helyzethez képest túlzott mértékben tenné lehetővé. ${ }^{47} \mathrm{~A}$ szerző a szükségállapot alkalmazhatóságával szemben öt ellenvetést tesz. Egyrészt a szükségállapot tényállásának a releváns fordulatából („az élet- és vagyonbiztonságot tömeges méretekben veszélyeztető, fegyveresen vagy felfegyverkezve elkövetett súlyos, erőszakos cselekmények") hiányzik a közvetlen fenyegetés megelőzésének különleges jogrendi lehetősége (ti. az előbbi súlyos, erőszakos cselekmények veszélye még nem alapozhatja meg a szükségállapot kihirdetését). A második kifogás a „tömeges méretekben” kitételre irányul, ugyanis álláspontja szerint ez csak a megtörtént és jelentős áldozatokat követelő eseményekre vonatkoztatható. Harmadrészt a szerző arra is utal, hogy „demokratikus deficit vádja merülhetne fel, amennyiben a köztársasági elnök egyszemélyi rendeleti államirányítása jönne létre a terrortámadás elhárítása okán". ${ }^{48}$ A negyedik ellenérvet - a rendkívüli állapothoz hasonlóan - az állampolgárok indokolatlan mértékû́ jogkorlátozása képezi. ${ }^{49}$ Végezetül az írás azt is hangsúlyozza, hogy a szükségállapot protokollja nem alkalmas a gyors reagálásra. ${ }^{50}$ Simicskóhoz hasonlóan Farkas Ádám is úgy vélekedik, hogy a terrorveszélyhelyzet a 2016-ban meglévő esetkörök egyikébe sem volt maradéktalanul beilleszthető. A szerző úgy jellemzi a terrorveszélyhelyzetet, mint a szükségállapot „előszoba-tényállását”, és ami ennélfogva a normál jogrend és a szükségállapot koordináta-rendszerében egy köztes megoldási lehetőség a hathatósabb állami fellépésre. ${ }^{51}$ Till Szabolcs a terrorveszélyhelyzet szükségességével kapcsolatban összességében szintén elfogadó álláspontot vesz fel egy 2016-os írásában..$^{52}$

A fenti megközelítésekkel szemben Mészáros Gábor úgy véli, hogy terrortámadás esetén is alkalmazható lenne a szükségállapot második fordulata, hiszen egy ilyen eseményt is minősíthetnénk úgy, mint az élet- és vagyonbiztonságot tömeges méretekben veszélyeztető, fegyveresen vagy felfegyverkezve elkövetett súlyos, erőszakos cselekmény, vagyis ez alapján - szól az érvelés - nem indokolt a szükségállapothoz képesti önálló szabályozás. ${ }^{53} \mathrm{~A}$ szerző

46 Simicskó, 2016. Az, hogy a megelőző védelmi helyzet, a váratlan támadás, valamint a veszélyhelyzet miért nem alkalmas a terrorveszély kezelésére, álláspontunk szerint egyértelmú, így a szerző ez irányú fejtegetéseinek bemutatásától eltekintünk.

47 Simicskó, 2016, 105. o.

48 Simicskó, 2016, 106. o. Ezzel kapcsolatban viszont adódik a kérdés: ha például egy puccskísérlet miatt kerül bevezetésre a szükségállapot, akkor ez az ellenérv ugyanúgy megállná-e a helyét?

49 Simicskó, 2016, 106. o.

50 Simicskó, 2016, 106. o.

51 Farkas, 2016a, 184. o.

52 Till, 2016.

53 Mészáros, 2017, 128-129. o. Megjegyzendő, hogy a szerző itt nem veszi figyelembe, hogy a jogszabályok megfogalmazása alapvetően egyes számban történik, viszont az Alaptörvény 48. cikk (1) bekezdés b) pontja következetesen többes számban fogalmaz („cselekmények”), azaz a szükségállapot kihirdetéséhez események sorozatára van szükség. Till a terrorveszélyhelyzettel kapcsolatban arra mutat rá, hogy a terrortámadás esetén „a megvalósult támadás felételének pedig egyszeri akció is eleget tehet, szemben a szükségállapoti tényállás többes számú megfogalmazásával" (Till, 2017, 66. o.). 
ezenfelül aggályosnak találja, hogy a terrorveszélyhelyzet alaptörvényi szabályozása alapján nem határozható meg pontosan, hogy mi minősül terrortámadásnak, illetve terrortámadás jelentős és közvetlen veszélyének, így fennáll annak a veszélye, hogy a Kormány visszaélésszerúen használhatja ki a szabályozás hiányosságait. ${ }^{54}$ Ósze Áron szintén a terrorveszélyhelyzet bevezetésének feleslegességét hangsúlyozza, és egyúttal úgy vélekedik, hogy a szükségállapot tényállásának bővitésével (a jelentős és közvetlen veszélyre történő utalás beemelésével) utóbbi különleges jogrend keretében is kezelhető lenne a terrorizmus fenyegetése. ${ }^{55}$ Ságvári Bence számos európai ország alkotmányának vizsgálatát követően arra a következtetésre jutott, hogy „a különleges jogrend kifejezetten terrorizmusra szabása nem európai gyakorlat", és egy újabb különleges jogrend hazánkban sem feltétlenül indokolt..

\section{A különleges jogrend átfogó reformja: az Alaptörvény kilencedik módosítása}

Az Alaptörvény 2020. decemberben elfogadott kilencedik módosítása (a továbbiakban: Módosítás) gyökeresen átalakította a különleges jogrendre vonatkozó szabályozást. A Módosítás általános indokolása védelmi és biztonsági reformról szól, és leszögezi, hogy a módosítás célja „a korszerúbb, a változó biztonsági környezethez jobban alkalmazkodó és az elmúlt évek válságkezeléseinek tapasztalataira építő, hatékony rendszer" kialakítása, hozzátéve, hogy az Alaptörvénybe többletgaranciákat is beépítenek. A részletes indokolás ezen túl megemlíti még az átláthatóságot és a fokozatosság elvét, mint a módosító javaslat során szem előtt tartott elveket. A különleges jogrendi rész rövidülésével járó reform ${ }^{57}$ legfontosabb elemeként a korábbi hat különleges jogrendi állapot helyett a Módosítás nyomán csak három kategória lesz megkülönböztetve: a hadiállapot, a szükségállapot és a veszélyhelyzet. ${ }^{58} \mathrm{Meg}$ ítélésünk szerint az átláthatóságot javítja, hogy a Módosítás - szemben a most hatályos szövegváltozattal - először végigveszi az egyes különleges jogrendeket, majd csak ezt követően tárgyalja a közös szabályokat. ${ }^{59}$

54 Mészáros, 2017, 129-130. o.

55 Ôsze, 2018, 40-41. o. Megjegyzendő ugyanakkor, hogy a terrorveszélyhelyzettel kapcsolatos ellenvélemények kevésbé veszik figyelembe, hogy a terrorveszélyhelyzetben más a rendkívüli jogosítványok címzettje, mint szükségállapotban, illetve az Alaptörvény azonnali intézkedéseket is lehetővé tesz a terrorveszélyhelyzet kezdeményezését követően, míg a szükségállapotnál ilyen lehetőség nincs.

56 Ságvári, 2016.

$57 \mathrm{Az}$ új különleges jogrendi rész terjedelme a jelenleginek mintegy háromnegyede.

58 Alaptörvény új 48. cikk.

59 Jelenleg a különleges jogrend tárgyalása a rendkívüli állapotra és a szükségállapotra vonatkozó közös szabályokkal indul (48. cikk), és ezt követően következik a rendkívüli állapot és a szükségállapot részletesebb tárgyalása. Ennek a megoldásnak az a hátránya, hogy pont a rendkívüli állapot címet viselő 49. cikkből nem derül ki a rendkívüli állapot lényege, hogy ti. mikor és ki által kerül sor ennek kihirdetésére. 
A következőkben először az egyes különleges jogrendekre vonatkozó szabályozás újdonságait mutatjuk be, majd a Kormány különleges jogrendi szerepének átalakulását tárgyaljuk, végül pedig a Módosítás által bevezetett többletgaranciákat vesszük számba. A változások ismertetése és értékelése előtt le kell szögezni, hogy az új különleges jogrendi rendelkezések meglehetősen soká, 2023. július 1-jén lépnek majd hatályba, ${ }^{60}$ így a - remélhetőleg minél kisebb számú válsághelyzeteket egy jó darabig még a hatályos szabályozás keretei között kell kezelni.

\subsection{A (régi-)új különleges jogrendek: hadiállapot, szükségállapot, veszélyhelyzet}

Az újonnan kialakított hadiállapot voltaképpen a katonai típusú különleges jogrendeket öleli fel, ${ }^{61}$ és - amint az indokolás rámutat - alapvetően a rendkívüli állapot elemeit ötvözi a megelőző védelmi helyzet egyes szabályaival. ${ }^{62} \mathrm{~A}$ következő ábra a rendkívüli állapot/hadiállapot kihirdetésére okot adó körülmények változását foglalja össze:

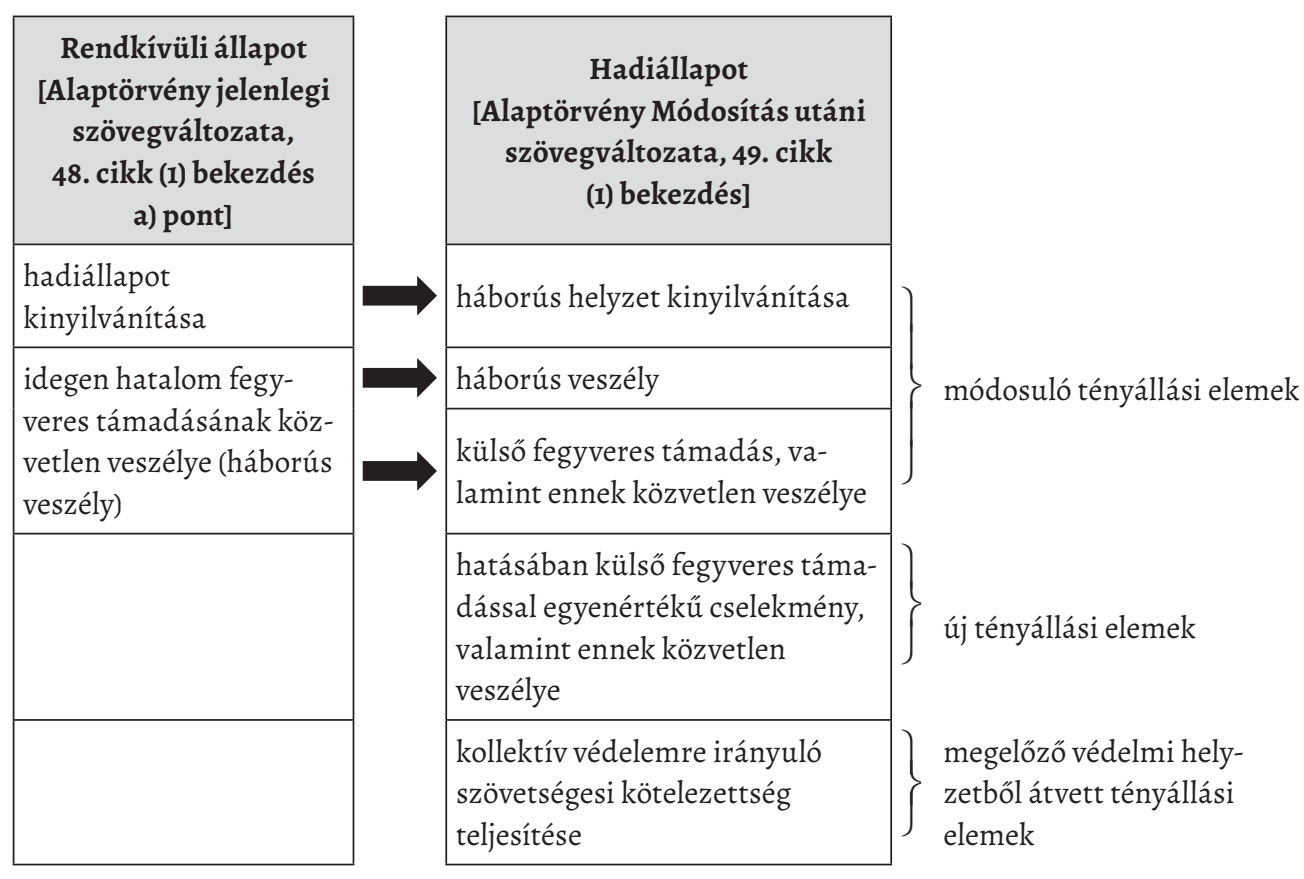

1. ábra

A rendkivüli állapotés a hadiállapot tényállási elemeinek változása az Alaptörvényben

Forrás: a szerzô saját összeállitása

60 Módosítás 12. cikk (2) bekezdés.

61 Alaptörvény új 49. cikk.

62 A Módosítás 11. cikkéhez füzött indokolás. 
Amint látható, a hadiállapot kifejezés fontos jelentésváltozáson esett át: míg az Alaptörvény jelenleg hatályos szövegében a hadiállapot (pontosabban annak kinyilvánítása) idézheti elő a rendkívüli állapotot, ${ }^{63}$ addig a Módosításban a hadiállapot már maga a különleges jogrend. Amint az indokolás kiemeli, a jelenlegi „hadiállapot kinyilvánítása” fordulat megegyezik az új „háborús helyzet kinyilvánítása” fordulattal. ${ }^{64} \mathrm{~A}$ második változást az jelenti, hogy az ,idegen hatalom fegyveres támadásának közvetlen veszélye (háborús veszély)" tényállás helyébe voltaképpen két fordulat lép. Az egyik a háborús veszély, ami abból a szempontból érdekes, hogy a jelenlegi szöveg is tartalmazza ezt a kifejezést, és a zárójeles feltüntetés arra utal, hogy a háborús veszély az idegen hatalom fegyveres támadásának közvetlen veszélyét jelenti. A Módosítás nyomán a háborús veszély fordulat "lecsupaszítva” megmarad - értve ez alatt azt, hogy ez a fogalom immár nem kerül kibontásra. A másik új fordulat a „külső fegyveres támadás, valamint ennek közvetlen veszélye”. Ez két szempontból is újdonságot hoz: egyrészt az „idegen hatalom fegyveres támadása” helyett az új szövegváltozat „külső fegyveres támadás”-ra utal, másrészt immár nemcsak ennek a közvetlen veszélye alapozhatja meg a hadiállapot kihirdetését, hanem maga a támadás is. ${ }^{65} \mathrm{Mindez}$ azt jelenti, hogy a hadiállapot - bár erre az indokolás nem utal - álláspontunk szerint magába olvasztja a jelenleg váratlan támadásnak nevezett különleges jogrendet is. A váratlan támadás kiváltó alapja az Alaptörvény hatályos szövegváltozatában a "külső fegyveres csoportoknak Magyarország területére történő váratlan betörése”; a hadiállapot „külső fegyveres támadás, valamint ennek közvetlen veszélye meghatározása" fordulata viszont kellően inkluzív ahhoz, hogy a külső fegyveres csoportok (például gerillacsoportok) ${ }^{66}$ betörésének kezelésére is alkalmas legyen. Míg tehát a rendkívüli állapot a reguláris hadviseléssel áll összefüggésben, addig a hadiállapot nemcsak a háborús helyzetet (veszélyt) öleli fel, hanem minden egyéb külső fegyveres támadást.

A harmadik változást az jelenti, hogy immár nemcsak a fegyveres támadás (illetve ennek közvetlen veszélye ${ }^{67}$ ) válthatja ki ezt a típusú különleges jogrendet, hanem - új

63 Vö.: Petrétei, 2015, 29-30. o. Amint Till kiemeli, jelenleg a hadiállapot nem jelent sui generis különleges jogrendi alakzatot [Till, 2019 (15)].

64 A Módosítás 5. cikkéhez füzött indokolás.

65 Bár ezzel kapcsolatban megjegyzendő, hogy ha a veszélyre való reagálás lehetséges, akkor - logikus módon a bekövetkezett támadásra is lehet reagálni.

66 A gerillacsoport mint példa elsőként az Alkotmány módosításáról szóló - a váratlan támadást beiktató 1993. évi CVII. törvény indokolásában jelent meg, és azóta több alkotmánykommentár is átvette.

67 A rendkívüli állapot jelenlegi „idegen hatalom fegyveres támadásának közvetlen veszélye” fordulatát Kelemen két szempontból is bírálja: ez a tényállási elem - álláspontja szerint - egyrészt szembehelyezkedik az Alaptörvény által elfogadott nemzetközi jogi szabályanyag fogalmaival (ti. „azt sugallja, hogy az önvédelmi cselekmények megvalósítását már preemptív megkezdheti a magyar állam, ami pedig sérti a nemzetközi jogi dogmatikát”), másrészt pedig „kizárja az állam szuverenitását veszélyeztető kisebb súlyú, de mégis fenyegető külső támadások hatékony kezelhetőségét (Kelemen, 2017, 52-54. o.). A szerző által jelzett problémák közül a másodikat véleményünk szerint megoldja a Módosítás, ugyanis immár mindenfajta külső fegyveres támadás megalapozhatja a rendkívüli állapot kihirdetését. 
elemként - a „hatásában külső fegyveres támadással egyenértékủ cselekmény” is. ${ }^{68}$ Ezen utóbbi kifejezés az indokolás szerint lehet akár a kibertérből érkező olyan rendkívüli erejû́ és átfogó támadás is, amely Magyarország szuverenitása szempontjából hasonló súlyúnak tekinthetô, mint egy fegyveres támadás. ${ }^{69}$ Végezetül a megelőző védelmi helyzet „beolvasztása” abban nyilvánul meg, hogy „kollektív védelemre irányuló szövetségesi kötelezettség teljesítése" esetén is hadiállapotot kell hirdetni. ${ }^{70}$ Mindez egyben azt is jelenti, hogy a kollektív védelmi kötelezettségen kívüli szövetségesi együttmúködés főszabály szerint normál jogrendi válságkezelés keretében kerül szabályozásra..$^{71}$

Az indokolás nemcsak a váratlan támadás „sorsát” nem említi, hanem a jelenlegi terrorveszélyhelyzet jövőjére sem tér ki. ${ }^{72}$ Míg a váratlan támadásról - a jelenleg hatályos szöveg és a módosítás egybevetését követően - kijelenthető, hogy a Módosítás nyomán a hadiállapotba fog betagolódni, addig a terrorveszélyhelyzetnél már valamivel nehezebb annak megítélése, hogy az ilyen típusú helyzetet a jövőben melyik különleges jogrendi kategóriában lehet majd kezelni. Ha abból indulunk ki, hogy a terrortámadás is egyfajta támadás, úgy azt - a hadiállapot második fordulata alapján - külső fegyveres támadásnak (vagy akár ezzel egyenértékú cselekménynek) is nevezhetjük. Amennyiben viszont a terrorra mint veszélyre helyezzük a hangsúlyt, úgy a szükségállapot második fordulata - az életés vagyonbiztonságot tömeges mértékben veszélyeztetô súlyos, jogellenes cselekmény - is alkalmazhatónak tûnik, ugyanis ezek az attribútumok a terrorcselekményre is igazak. ${ }^{73}$ Összességében úgy véljük, hogy az alkotmányozó tisztább helyzetet teremtett volna, ha legalább az indokolásban utal arra, hogy a sui generis különleges jogrendi kategóriaként megszûnő váratlan támadás és a terrorveszélyhelyzet a jövőben hogyan kerül majd kezelésre. ${ }^{74}$

A szükségállapot kihirdetésére okot adó körülmények kisebb változáson estek át, ${ }^{75}$ ezeket a következő ábra foglalja össze:

68 Alaptörvény új 49. cikk (1) bekezdés b) pont.

69 A Módosítás 11. cikkéhez füzött indokolás.

70 Alaptörvény új 49. cikk (1) bekezdés c) pont.

71 A 11. Módosítás cikkéhez füzött indokolás.

72 Természetesen az is elképzelhető, hogy a terrorveszélyre vagy a terrortámadásra történő reakció a későbbiekben törvényi szinten kerül szabályozásra.

73 Vö.: Mészáros, 2017, 128. o.; Kelemen, 2017, 60. o. Utóbbi szerző úgy vélekedik, hogy a terrorveszélyhelyzet a szükségállapot egy speciálisnak nevezhető formája.

74 A másik megoldás az lett volna, ha az Alaptörvény kilencedik módosításához is készül egy olyan „fordítókulcs", amely világosan szabályozza, hogy egy esetlegesen már kihirdetett különleges jogrendre a módosított Alaptörvény mely rendelkezéseit kell alkalmazni.

75 Alaptörvény új 50. cikk (1) bekezdés. 


\begin{tabular}{|c|c|}
\hline $\begin{array}{c}\text { Szülkségállapot } \\
\text { [Alaptörvény jelenlegi szövegváltozata, } \\
\text { 48. cikk (1) bekezdés b) pont] }\end{array}$ & $\begin{array}{c}\text { Szükségállapot } \\
\text { [Alaptörvény Módosítás utáni szövegvál- } \\
\text { tozata, 50. cikk (1) bekezdés] }\end{array}$ \\
\hline $\begin{array}{c}\text { a törvényes rend megdöntésére vagy a ha- } \\
\text { talom kizárólagos megszerzésére irányuló } \\
\text { fegyveres cselekmények }\end{array}$ & $\begin{array}{c}\text { az alkotmányos rend megdöntésére, } \\
\text { felforgatására vagy a hatalom kizárólagos } \\
\text { megszerzésére irányuló cselekmény }\end{array}$ \\
\hline $\begin{array}{c}\text { az élet- és vagyonbiztonságot tömeges } \\
\text { méretekben veszélyeztetó, fegyveresen vagy } \\
\text { felfegyverkezve elkövetett súlyos, erószakos } \\
\text { cselekmények }\end{array}$ & $\begin{array}{c}\text { az élet- és vagyonbiztonságot tömeges } \\
\text { mértékben veszélyeztető súlyos, jogellenes } \\
\text { cselekmény }\end{array}$ \\
\hline
\end{tabular}

2. ábra

A szükségállapot tényállási elemeinek változása az Alaptörvényben

Forrás: a szerző sajátösszeállítása

Összességében megállapítható, hogy a Módosítás következtében valamelyest lazultak a szükségállapot kihirdetésének feltételei:

— immár nemcsak az alkotmányos (korábbi kifejezéssel: törvényes) rend megdöntésére, hanem annak „csak” a felforgatására irányuló cselekmény is megalapozhatja a szükségállapot kihirdetését;

— a tényállási elemek közül kikerültek a „fegyveres(en)”/,felfegyverkezve” kifejezések;

- az élet- és vagyonbiztonságot tömeges méretekben veszélyeztető, súlyos, erőszakos cselekménynek immár nem kell erőszakosnak, „csak” jogellenesnek lennie;

- míg az Alaptörvény hatályos változata a diszpozícióban - a jogszabályszerkesztési elôírásokra figyelemmel kissé szokatlan módon - többes számban beszél fegyveres, illetve erőszakos cselekményekról, ${ }^{76}$ addig a Módosítás - talán éppen a terrorveszélyhelyzet beolvasztása érdekében - egyes számra vált, amely arra utal, hogy akár egyetlen ilyen cselekmény is megalapozhatja a szükségállapot kihirdetését.

A szükségállapotot megalapozó körülmények tágításának az indokolás szerint az az oka, hogy az alkotmányozó fel kíván készülni a létfontosságú infrastruktúrák, illetve az információs technológia felforgató, ártó, támadó célra való alkalmazhatóságára. ${ }^{77}$

Fontos változás, hogy a szükségállapot a jövőben csak 30 napra lesz kihirdethető, de ezt az Országgyưlés a képviselők kétharmadának szavazatával 30 nappal meghosszabbíthatja, ha a kihirdetésére okot adó körülmény továbbra is fennáll. ${ }^{78}$ Ezenfelül további újítás, hogy

76 Till, 2016, 36-37. o.; Till, 2019, [21]. Az előbbi írásában a szerző szerint „[k]érdéses ugyanis, hogy például egy nagyobb horderejü, de elszigetelt [tehát egyetlen - H. A.] merénylet önmagában alkalmas-e a szükségállapot megalapozására". A Módosítás nyomán erre a kérdésre elvileg már egyértelmúen igenlő választ lehet adni. 77 A Módosítás 11. cikkéhez fúzött indokolás.

78 Alaptörvény új 50. cikk (3) bekezdés. 
a Módosítás nyomán kikerül az Alaptörvényből a Magyar Honvédség szükségállapot idején történő felhasználását lehetővé tevő rendelkezés. ${ }^{79}$

A veszélyhelyzet kihirdetésére okot adó körülmények szintén kisebb mértékben módosultak.

\begin{tabular}{|c|}
\hline $\begin{array}{c}\text { Veszélyhelyzet } \\
\text { [Alaptörvény jelenlegi szövegváltozata, } \\
\text { 53. cikk (1) bekezdés] }\end{array}$ \\
\hline $\begin{array}{c}\text { az élet- és vagyonbiztonságot veszélyeztető } \\
\text { elemi csapás vagy ipari szerencsétlenség } \\
\text { esetén }\end{array}$ \\
\hline
\end{tabular}

3. ábra

A veszélyhelyzet tényállási elemeinek változása az Alaptörvényben

Forrás: a szerző saját összeállítása

A Módosítás nyomán az elemi csapás és az ipari szerencsétlenség csak példálózó módon jelenik meg, azaz egyéb, az élet- és vagyonbiztonságot veszélyeztetô súlyos esemény esetén is lehetőség nyílik veszélyhelyzet kihirdetésére. ${ }^{80}$ (Ezzel a szövegpontosítással tehát elhárulnak az Alaptörvény és a katasztrófavédelmi törvény ütközésére hivatkozó - a következő fejezetben részletesen is bemutatott - aggályok.)

Részben valószínúleg a 2020. tavaszi jogértelmezési dilemmákra is reagálva ${ }^{81}$ a Módosítás konkrét időbeli keretet szab, amikor kimondja, hogy a veszélyhelyzet - a szükségállapothoz hasonlóan - 30 napra hirdethetô ki. ${ }^{82}$ Amint az közismert, a jelenleg hatályos alaptörvényi szabályozás értelmében a veszélyhelyzet addig tart, amíg a Kormány meg nem szünteti - viszont a veszélyhelyzeti rendeletek csak 15 napig maradnak hatályban (kivéve, ha a Kormány - az Országgyưlés felhatalmazása alapján - a rendelet hatályát meghosszabbítja). A Módosítás hatálybalépését követően ez a kettősség megszúnik, és mind a veszélyhelyzet - 30 napon túli - időtartama, mind pedig a veszélyhelyzeti kormányrendeletek hatálya az Országgyưlés döntésétől függ. Ez egyrészt azt jelenti, hogy a veszélyhelyzet 30 napon túl csak akkor tartható fenn, ha az Országgyúlés felhatalmazza a Kormányt a meghosszabbítására, ${ }^{83}$ másrészt viszont a veszélyhelyzeti kormányrendeletek hatályának meghosszabbítására nem lesz szükség, ugyanis ezek egészen addig hatályban maradnak, amíg az Országgyúlés hatályon kívül nem helyezi ôket (erre bármikor lehetősége van a törvényhozásnak), vagy meg nem szünik a veszélyhelyzet. Röviden tehát: eddig a veszélyhelyzeti kormányrendeletek hatályának meghosszabbításához kellett

79 Alaptörvény 50. cikk (1) bekezdés. A változás oka nem derül ki a Módosítás indokolásából. Elképzelhető, hogy a jövőben törvényi szinten kerül majd rögzítésre egy hasonló tartalmú rendelkezés.

80 Alaptörvény új 51. cikk (1) bekezdés.

81 Erről lásd a 6. fejezet 6. pontját.

82 Alaptörvény új 51. cikk (2) bekezdés.

83 Alaptörvény új 51. cikk (3) bekezdés. 
az Országgyưlés, ezentúl viszont a veszélyhelyzet időtartamának meghosszabbításához lesz szükség a parlamenti felhatalmazásra. Álláspontunk szerint ez az újitás abból a szempontból kétségtelenül szerencsés, hogy egyszerre egyszerüsíti a Kormány helyzetét (ti. nem lesz szükség a veszélyhelyzeti rendeletek hosszabbítgatására) és növeli a parlamenti kontrollt (ti. az Országgyû́lés bármelyik veszélyhelyzeti rendeletet bármikor hatályon kívül helyezheti). ${ }^{84}$

A Módosítás veszélyhelyzetre vonatkozó rendelkezései egy további pontosító jellegú kiegészítést tesznek azzal, hogy rögzítik, hogy a veszélyhelyzet meghosszabbításához adott felhatalmazásához az Országgyûlés a jelen lévő országgyưlési képviselők kétharmadának szavazatával dönt. A hatályos szabályozás nem utal a kétharmados többségre a veszélyhelyzeti rendeletek hatályának meghosszabbítása vonatkozásában, amiből az következik, hogy ehhez elegendő az abszolút többség. ${ }^{85}$

Végezetül egy további, mindhárom különleges jogrendet érintő - az indokolásban nem említett - változásra hívjuk fel a figyelmet: a tényállások körülírását követően az egyértelmú kötelezésre utaló hirdet igét a hirdethet kifejezés váltotta fel, vagyis az Országgyúlés/Kormány ezekben a helyzetekben „csak” kihirdetheti az adott különleges jogrendet. A -het képző beszúrásából az következik, hogy az Országgyúlésnek/Kormánynak - elvileg - mérlegelési joga van a kihirdetést illetően. ${ }^{86}$

\subsection{A Kormány átalakuló szerepe}

Az Alaptörvény kilencedik módosítása nyomán különleges jogrendben a Kormánynak rendkívüli módon megnő a szerepe, és egyben a felelőssége is. A különleges jogrendi rendeletalkotás címzettje immár minden esetben a Kormány, azaz a Módosítás általános jelleggel, mindhárom különleges jogrendi helyzetre kiterjedően mondja ki, hogy a Kormány rendeletet alkothat. ${ }^{87}$ (A rendeletek jellemzői - ti. hogy abban a Kormány sarkalatos törvényben meghatározottak szerint egyes törvények alkalmazását felfüggesztheti, törvényi rendelkezésektől eltérhet, valamint egyéb rendkívüli intézkedéseket hozhat - változatlanok maradnak.) A Kormány súlyának növekedését az indokolás azzal magyarázza, hogy „a különleges jogrend kihirdetését kö-

84 Amint a 6. fejezetből kiderül, a veszélyhelyzeti kormányrendeletek meghosszabbítása több szempontból is problémásnak minősült 2020 tavaszán.

85 Annak, hogy a koronavírus elleni védekezésről szóló 2020. évi XII. törvény (a továbbiakban: Kevtv.) sarkalatosnak minősült, azaz kétharmados többséget igényelt, az volt az oka, hogy - amint a sarkalatossági záradékból (9. \$) kiderül - a törvény több olyan tárgykört [például az Alkotmánybíróság múködése (5. \$)] szabályozott, amelyek csak kétharmados többséggel módosíthatók. Azt is itt kell megjegyezni, hogy a meghosszabbítás egyáltalán nem igényel törvényi formát, hiszen az országgyúlési határozat keretében is megadható (erről lásd a 6. fejezet 6. pontját).

86 Mindez különösen azokban az esetekben bírhat relevanciával, amikor valamely különleges jogrend kihirdetéséhez szükséges körülmények mintegy objektív módon, egyértelmúen eldönthetők - például beáll a háborús helyzet. Kérdés, hogy ilyenkor az Országgyủlésnek van-e tényleges mérlegelési joga.

87 Alaptörvény új 53. cikk (1) bekezdés. Megjegyzendő, hogy a szakirodalomban már korábban is volt olyan javaslat, amely szerint minden esetben a Kormánynak kellene lennie a felhatalmazás címzettjének és a felelősség viselőjének (Farkas, 2020a, 369. o.). 
vetően gyors, operatív és mind politikai, mind jogi értelemben felelős döntéshozatal biztosítása szükséges, amire a magyar alkotmányos rendszerben a Kormány mutatkozik alkalmasnak". Mindez azt jelenti, hogy az alkotmányozó egyrészt felszámolja a mintegy 170 éves elóképpel rendelkező Honvédelmi Tanácsot, ${ }^{88}$ másrészt megszünteti a köztársasági elnök rendeletalkotási jogát. A Honvédelmi Tanács jelenlegi szerepét lényegében a Kormány fogja betölteni azzal, hogy a köztársasági elnök jogkörét a Kormány ilyenkor sem veszi át (bár megjegyzendő, hogy a köztársasági elnök jogosult a hadiállapot kihirdetésére, a szükségállapot kihirdetésére és meghoszszabbítására, valamint arra, hogy felhatalmazza a kormányt a veszélyhelyzet meghosszabbítására, ha az Országgyúlés e döntések meghozatalában akadályoztatva van). ${ }^{89}$

A Módosítás világosabb keretet teremt a kormányrendeletek parlamenti kontrollja vonatkozásában is, ugyanis általános érvénnyel, valamennyi különleges jogrendre kiterjedően rögzítésre kerül, hogy az Országgyưlés a Kormány által különleges jogrend idején a különleges jogrendre vonatkozó szabályok szerint alkotott rendeletet hatályon kívül helyezheti. ${ }^{90} \mathrm{Az}$ Alaptörvény ezt a kontrollszerepet jelenleg komplikáltabban, különleges jogrendenként eltérően szabályozza. ${ }^{91}$ A Módosítás másrészt - egy potenciális „kiskaput” bezárva - azt is tisztázza, hogy az Országgyưlés által hatályon kívül helyezett rendeletet a Kormány azonos tartalommal nem alkothatja meg újra, kivéve ha azt a körülmények jelentős változása indokolja..$^{92}$

A Módosítás azt is lehetôvé teszi a Kormánynak, hogy bizonyos esetekben már a különleges jogrend kihirdetése elött megkezdje a válsághelyzet kezelését. Erre akkor kerülhet sor, ha a Kormány már kezdeményezte a hadiállapot vagy a szükségállapot parlamenti kihirdetését, azonban még nem született meg az Országgyúlés erre vonatkozó döntése. Ezekben a - nevezzük így - előzetes rendeletekben a Kormány pontosan ugyanazokat teheti meg, mint a különleges jogrendi rendeletekben (ti. - sarkalatos törvényben meghatározottak szerint - a kihirdetésre okot adó körülmény azonnali kezeléséhez szükséges mértékben egyes törvények alkalmazását felfüggesztheti, törvényi rendelkezésektől eltérhet, valamint egyéb rendkívüli intézkedéseket hozhat). ${ }^{93} \mathrm{Az}$ előzetes rendeletek hatálya a hadiállapot vagy a szükségállapot kihirdetésére vonatkozó döntésig, de legfeljebb a kihirdetés Kormány általi kezdeményezésétől számított 60 napig, hadiállapot vagy szükségállapot kihirdetése esetén legfeljebb a hadiállapot vagy a szükségállapot megszűnéséig tart. ${ }^{94}$ Erre a kezdeményezés és a döntés közötti időszakra is vonatkoznak a - későbbiekben ismertetendő - garanciák (az Országgyuulés és az Alkotmánybíróság folyamatos múködésének szavatolása), valamint a már említett azonos tartalmú jogalkotás tilalma. ${ }^{95}$ További újítást jelent, hogy a módosítás azt a helyzetet is rendezi, amikor

88 A honvédelmi jellegú, (többnyire) kivételes hatalmi szervek bemutatására lásd: Kelemen, 2020. A szerző egyúttal arra is felhívja a figyelmet, hogy ezek a szervek csak korlátozottan tekinthetők egymás elődjeinek/utódjainak.

89 Alaptörvény új 56. cikk (1) bekezdés.

90 Alaptörvény új 53. cikk (3) bekezdés.

91 Alaptörvény 48. cikk (6) bekezdés, 50. cikk (4)-(5) bekezdés, 51/A. cikk (3) bekezdés, 53. cikk (3) bekezdés.

92 Alaptörvény új 53. cikk (3) bekezdés.

93 Alaptörvény új 54. cikk (1) bekezdés.

94 Alaptörvény új 54. cikk (3) bekezdés.

95 Alaptörvény új 54. cikk (5)-(7) bekezdés. 
a Kormány hozott ugyan előzetes rendeleteket, azonban a hadiállapot vagy a szükségállapot kihirdetésére végül nem kerül sor. Ekkor az Országgyúlés törvényt alkot a kormányrendeletekben hozott rendkívüli intézkedésekkel összefüggő szabályozási átmenetről. ${ }^{96}$

Arra is rá kell mutatni, hogy a Módosítás tisztázza azt a kérdést, hogy a különleges jogrend megszúnésekor pontosan mely kormányrendeletek vesztik hatályukat. Az Alaptörvény jelenleg a terrorveszélyhelyzet, a váratlan támadás, valamint a veszélyhelyzet esetén is úgy fogalmaz, hogy „[a] Kormány rendelete a veszélyhelyzet megszünésével hatályát veszti”. ${ }^{97} \mathrm{Ez}$ a megfogalmazás - különösen a határozott névelő miatt - azért nem szerencsés, mert nem derül ki belőle egyértelmúen, hogy a hatályvesztés valamennyi, a különleges jogrend keretében meghozott rendeletre vonatkozik (tehát azokra is, amelyeket a kormány normál jogrendben is meghozhatott volna), vagy csak azokra, amelyeket a különleges jogrendi felhatalmazás alapján hozott meg.98 A módosítás úgy tisztázza ezt a kérdést, hogy leszögezi: „A Kormány által különleges jogrend idején a különleges jogrendre vonatkozó szabályok szerint alkotott rendelet a különleges jogrend megszúnésekor hatályát veszti". ${ }^{99}$ A különleges jogrendre vonatkozó szabályok szerint alkotott rendelet kitétel egyértelmúen az utóbbi értelmezést teszi irányadóvá.

A fenti módosítások értékelését értelemszerủen megnehezíti az a tény, hogy - szerencsére - sem a Honvédelmi Tanács, sem pedig az államfó rendeletalkotásáról nincsenek tapasztalataink, vagyis az Alaptörvény módosítása csak elméletben létező, de a gyakorlatban soha nem múködő intézményeket számolt fel. Ennek megfelelően a változások értékelése során a tapasztalatok értelemszerúen nem szolgálhatnak kiindulópontul, vagyis jobbára csak elméleti síkon lehet megközelíteni ezen kérdéseket.

Ami a köztársasági elnök rendeletalkotási jogkörét illeti, kevés érv hozható fel amellett, hogy az államfő pont szükségállapot idején - azaz egy kiélezett, az állam létét fenyegető helyzetben - kapjon „válságmenedzselő” szerepet. Szente Zoltán szerint a „Magyarországon immár hagyományosan gyenge és funkciótlan államfő kiemelt szerepe már a rendkívüli és a szükségállapot tekintetében is indokolatlan - csupán szimbolikus jellegú, illetve tradíción alapul - [...]". ${ }^{100}$ A hatályos szabályozás szerint komoly államfói jogosítvány, hogy szükségállapot idején az Országgyưlés akadályoztatása esetén a köztársasági elnök dönt a Magyar Honvédség felhasználásáról, ha a rendőrség és a nem-

96 Alaptörvény új 54. cikk (4) bekezdés.

97 Alaptörvény 51/A. cikk (6) bekezdés; 52 . cikk (4) bekezdés; 53. cikk (4) bekezdés.

98 A kérdés némileg más kontextusban a 2020. tavaszi veszélyhelyzetben is felmerült. Ebben az esetben az volt a kérdés, hogy a 15 nap utáni hatályvesztés azokra a rendelkezésekre is vonatkozik-e, amelyeket a Kormány nem veszélyhelyzeti jogszabályként, hanem törvényi felhatalmazás alapján alkotott meg. Ilyen volt például a határellenőrzés visszaállítása [az élet- és vagyonbiztonságot veszélyeztető tömeges megbetegedést okozó humánjárvány megelőzése, illetve következményeinek elhárítása, a magyar állampolgárok egészségének és életének megóvása érdekében elrendelt veszélyhelyzet során teendő intézkedésekről szóló 41/2020. (III. 11.) Korm. rendelet 1. \$], amely az államhatárról szóló 2007. évi LXXXIX. törvény 16. \$ (4) bekezdés c) pontjában kapott felhatalmazáson alapult. A problémáról bővebben lásd: Salgó, 2020, 15. o.

99 Alaptörvény új 53. cikk (5) bekezdés.

100 Szente, 2020, 126. o. 
zetbiztonsági szolgálatok alkalmazása nem elegendő. ${ }^{101}$ Emellett szükségállapotban a köztársasági elnöknek kellene a honvédelmi törvényben ${ }^{102}$ meghatározott rendkívüli intézkedéseket bevezetni. ${ }^{103}$ Ezek nagyrészt olyan döntések (mint például a média korlátozása, forgalmi és utazási korlátozások, az igazságszolgáltatásra vonatkozó rendkívüli intézkedések), amelyek álláspontunk szerint egyrészt teljességgel idegenek a hazai köztársasági elnöki tisztségtől, és kétséges, hogy a napi igazgatási feladatoktól távolságot tartó, kis létszámú apparátussal rendelkező, jogi és politikai felelősséget nem viselő államfó mennyiben lenne képes adekvát döntéseket hozni szükségállapot idején (még akkor is, ha ilyen helyzetben valószínúleg folyamatos lenne a konzultáció a köztársasági elnök és a Kormány között). ${ }^{104}$ Másrészt az Alaptörvény alapján az sem világos, hogy szükségállapot idején a Kormány miért szorul háttérbe, hiszen az előbbi rendkívüli intézkedéseket a Kormány is meg tudná hozni. (Az államfó előtérbe helyezésének esetleg az lehet az oka, hogy a szükségállapotot kiváltó „belső” veszély esetén szimbolikus erôvel bír, hogy a nemzet egységét megtestesítő köztársasági elnök lesz a válságkezelés „arca”.) A köztársasági elnöknek jelenleg a rendkívüli állapot esetén is van szerepe, hiszen az ilyenkor megalakuló Honvédelmi Tanácsnak az elnöke, azonban itt egy olyan hibrid testületról van szó, amely átfogja a törvényhozó és a végrehajtó hatalmat is, ${ }^{105}$ de összességében a Kormány (tagjai) van(nak) benne többségben, ${ }^{106}$ vagyis itt közel sem lenne olyan meghatározó az államfó szerepe, mint szükségállapot idején. ${ }^{107}$

101 Alaptörvény 50. cikk (2) bekezdés.

102 A honvédelemről és a Magyar Honvédségről, valamint a különleges jogrendben bevezethetô intézkedésekről szóló 2011. évi CXIII. törvény (a továbbiakban: Hvt.).

103 Hvt. 64. \$ (3) bekezdés. Mészáros úgy fogalmaz, hogy „[b]ár a rendkívüli intézkedések megtételére a köztársasági elnök jogosult, valójában az Országgyưlés kétharmados többsége által elfogadott sarkalatos törvényben meghatározott intézkedések rendeleti úton történő elrendelésére korlátozódik a jogköre" (Mészáros, 2017, 120.). Ez a megközelítés inkább az államfő mozgásterének korlátaira helyezi a hangsúlyt, azonban arra is rá kell mutatni, hogy a Hvt. előbb hivatkozott rendelkezése számos rendkívüli intézkedés bevezetését teszi lehetővé a köztársasági elnök részére, azaz álláspontunk szerint az államfőnek meglehetősen nagy a mozgástere abban, hogy a több tucat intézkedés közül melyeket és hogyan vezeti be.

104 Vö.: Kelemen, 2017. 65. o. A szerző szerint „[a]z államfő ilyetén jogokkal való felruházása visszavezethető a polgári kori magyar jogi hagyományokra, ahol elóbb a király, majd a kormányzó birtokolt hasonló jogköröket, azonban ezen korszakban mindkettőnek erős jogi kapcsolata volt a végrehajtó hatalommal, sőt több tekintetben annak részeként fungált".

105 Vö.: Farkas-Kádár, 2016, 306. o.; Petrétei, 2015, 34-44. o.

106 Vö.: Till. 2019 [37]. Egyúttal arra is rá kell mutatni, hogy a Honvédelmi Tanácsban a tagok többsége mellett a Kormány mintegy „feloldódik”: mivel a testület ellátja a Kormány feladatait is, végső soron nemcsak a törvényeket rontanák le a Honvédelmi Tanács rendeletei, hanem egy esetleges korrekció esetén a kormányrendeleteket is „fel kellene húzni” erre a szintre.

107 Ugyanakkor a Honvédelmi Tanáccsal szemben is megfogalmazható kritika: Till szerint aggályos, hogy „éppen az állami múködés legnagyobb veszélyeztetését hivatott egy olyan állami intézmény kezelni, amelynek nincs alkalma a múködési gyakorlat megszerzésére" [Till, 2019, (37)]. Kovács további anomáliákat fogalmaz meg a Honvédelmi Tanáccsal kapcsolatban, rámutatva, hogy nem világosak a felelősségi viszonyok és a múködési kérdések (Kovács, 2015, 141-142. o.). 
Összességében megállapítható, hogy a Kormány súlya és felelőssége valóban megnő a Módosítás nyomán, és ezzel együtt a köztársasági elnök szerepe visszaszorul. Utóbbi a szükségállapot során játszott központi szerep megszüntetésében nyilvánul meg, viszont néhány területen megmaradnak az államfő jogosítványai. Így a köztársasági elnök jogosult a hadiállapot kihirdetésére, a szükségállapot kihirdetésére és - új jogkörként - meghoszszabbítására, valamint arra, hogy felhatalmazza a Kormányt a veszélyhelyzet meghosszabbítására, ha az Országgyúlés e döntések meghozatalában akadályoztatva van. ${ }^{108}$ Ezenfelül a Kormányt az államfő irányában is tájékoztatási kötelezettség terheli a különleges jogrendre vonatkozó szabályok szerint alkotott rendeletekről.

\subsection{Többletgaranciák}

Amint fentebb már utaltunk rá, a módosítás az Alaptörvénybe többletgaranciákat is beépít. Az egyik újdonság az Országgyúlésre vonatkozik: „A Kormány különleges jogrend idején köteles minden olyan intézkedést megtenni, amely az Országgyưlés folyamatos mứködését szavatolja.”109 (Sőt, a módosítás később úgy fogalmaz, hogy a Kormány már a hadiállapot vagy a szükségállapot kihirdetésének kezdeményezését követően köteles az Országgyuulés folyamatos múködését szavatoló intézkedést megtenni. ${ }^{1{ }^{10}}$ )

Az Országgyưlés folyamatos múködésével kapcsolatban 2020 tavaszán is merültek fel kérdőjelek, és a koronavírus elleni védekezésről szóló törvény által a Kormánynak biztosított általános (ellenzéki olvasatban „biankó”) felhatalmazás egyik indoka az volt, hogy „Magyarország Kormánya abban az esetben is megalkothassa és hatályában fenntarthassa a rendkívüli rendelkezéseket tartalmazó rendeleteit, ha az Országgyúlés bármely, a Covid-19-fertőzés okozta tömeges megbetegedést okozó, 2020. évben bekövetkezett humánjárvánnyal összefüggő okból nem ülésezik". ${ }^{111}$ Sőt, a törvény preambuluma is utalt arra, hogy a jogalkotó kifejezetten számol azzal a lehetőséggel, hogy az Országgyúlés ülésezése a humánjárvány következtében szünetelhet. A módosítás nyomán adott a kérdés: a Kormány vajon hogyan tudja szavatolni az Országgyúlés folyamatos múködését? Tekintve, hogy a Kormánynak közjogi szempontból lényegében nincs szerepe vagy ráhatása az Országgyưlés múködésére, itt valószínúleg az infrastruktúra biztosítására kell gondolni. A járványveszélyhelyzet rávilágított, hogy a jelenlegi jogi szabályozás abból a szempontból kétségtelenül rugalmatlan, hogy az Országgyưlés csak jelenléti módon tud múködni. ${ }^{112}$ (A Kormány számára mindez egyben

108 Alaptörvény új 56. cikk (1) bekezdés.

109 Alaptörvény új 52. cikk (3) bekezdés.

110 Alaptörvény új 54. cikk (5) bekezdés.

111 A Kevtv. általános indokolása.

112 Egy 2020 tavaszán végzett, 159 ország parlamentjének járványveszélyhelyzeti múködését vizsgáló kutatás azt vizsgálta, hogy az egyes országok mennyiben tették lehetôvé az infokommunikációs eszközök használatát a parlamentben. Az eredmények alapján a vizsgált parlamentek kb. 45\%-a engedett kisebb-nagyobb teret az elektronikus múködésnek; a többi ország (köztük Magyarország is) viszont semmilyen technológiai újítást nem vezetett be (Bar-Siman-Tov et al., 2021, 120.). 
hivatkozási alapot jelentett az Országgyuulés elektronikus szavazását és távolléti múködését szorgalmazó álláspontokkal szemben, megvédve egyúttal a Kevtv. általános felhatalmazási rendelkezését. ${ }^{113} \mathrm{~A}$ fentiek alapján tehát elképzelhető, hogy a jövőben megteremtődik az alaptörvényi/jogszabályi alapja annak, hogy az Országgyúlés ne csak jelenléti módon ülésezhessen és szavazhasson. ${ }^{114}$

A másik többletgarancia az Alkotmánybíróságot érinti: azt ugyan a jelenleg hatályos szöveg is rögzíti, hogy az Alkotmánybíróság múködése különleges jogrend esetén sem korlátozható, ${ }^{115}$ azonban a módosítás ezt kiegészíti azzal, hogy „[a] Kormány különleges jogrendben köteles minden olyan intézkedést megtenni, amely az Alkotmánybíróság folyamatos múködését szavatolja". ${ }^{116}$ A Kormány ezen kötelezettsége már a hadiállapot vagy a szükségállapot kihirdetésének kezdeményezését követően él. ${ }^{117}$ (Itt kell megjegyezni, hogy az elektronikus kommunikációs eszköz igénybevételével történő ülésezést már a Kevtv. is lehetôvé tette a testületnek. $)^{118}$

Kisebb, inkább csak szimbolikus jelentőségú az a módosítás, amelyik valamennyi különleges jogrendre vonatkozóan előírja a Kormány tájékoztatási kötelezettségét. A Kormánynak tehát a különleges jogrendre vonatkozó szabályok szerint alkotott rendeletről - beleértve a veszélyhelyzeti rendeleteket, valamint az előzetes rendeleteket is - folyamatosan tájékoztatnia kell a köztársasági elnököt, az Országgyuúlés elnökét és az Országgyưlés tárgykör szerint feladat- és hatáskörrel rendelkező állandó bizottságát. ${ }^{119}$ (A Kormánynak jelenleg csak megelőző védelmi helyzetben, ${ }^{120}$ terrorveszélyhelyzetben ${ }^{121}$ és váratlan támadás esetén ${ }^{122}$ van ilyen tájékoztatási kötelezettsége, de az első kettőben a címzettek között nem szerepel az Országgyúlés [csak az Országgyưlés tárgykör szerint feladat- és hatáskörrel rendelkező állandó bizottsága]).

113 „S még egyszer: a parlament ülésezésével kapcsolatban korábban az elektronikus szavazás és egyéb ötletek is elhangzottak. Az Alaptörvény csak arról rendelkezik, hogy a jelen lévő képviselők szavazatával hozza meg az Országgyưlés döntéseit. Van ugyan utalás arra, hogy más helyszínen is ülésezhet az Országgyưlés, de nyilván nem a virtuális térre alkotódott ez a fogalom" - mutatott rá Völner Pál, az Igazságügyi Minisztérium parlamenti államtitkára a Kevtv. országgyúlési vitája során. Elérhető: https://tinyurl.com/1bdow7nf (Letöltve: 2020 . december 1.).

114 A témakörben 2020. novemberben már született egy ellenzéki javaslat az Alaptörvény módosítására, amelynek értelmében Az Alaptörvény 53. cikke a következő (3a) bekezdéssel egészülne ki:

„(3a) Az Országgyúlés elnöke gondoskodik az Országgyúlés veszélyhelyzet ideje alatti múködéséhez és ülésezéséhez szükséges intézkedésekről. A határozatképességhez szükséges jelenlét elektronikus kommunikációs eszköz igénybevételével is biztosítható." Elérhetô: www.parlament.hu/irom41/13656/13656.pdf (Letöltve: 2020. december 1.).

115 Alaptörvény 54. cikk (2) bekezdés.

116 Alaptörvény új 52. cikk (4) bekezdés.

117 Alaptörvény új 54. cikk (7) bekezdés.

118 Kevtv. 5. \$ (2) bekezdés.

119 Alaptörvény új 53. cikk (2) bekezdés.

120 Alaptörvény 51. cikk (3) bekezdés.

121 Alaptörvény 51/A. cikk (3) bekezdés.

122 Alaptörvény 52. cikk (2) bekezdés. 
Végezetül megjegyzendő, hogy az újonnan bevezetendő garanciák sorát gyarapítja az a - fentebb már hivatkozott - rendelkezés, miszerint az Országgyúlés által hatályon kívül helyezett rendeletet a Kormány azonos tartalommal nem alkothatja meg újra (kivéve, ha azt a körülmények jelentős változása indokolja).

\section{3. Összegzés - A különleges jogrend rendszerváltás utáni evolúciója}

Amint arra a tanulmány címe is utal, a különleges jogrendre vonatkozó alkotmányos szabályozás egy sajátos utat járt be a rendszerváltás óta eltelt három évtizedben. A 4. ábra összefoglaló jelleggel illusztrálja a különleges jogrend fejlődését, rávilágítva, hogy a három kezdeti kategória előbb fokozatosan hatra emelkedett, majd a kilencedik Alaptörvény-módosítás - legalábbis mennyiségileg - visszatérést jelent a „kiinduló" 1989-es állapotokhoz.

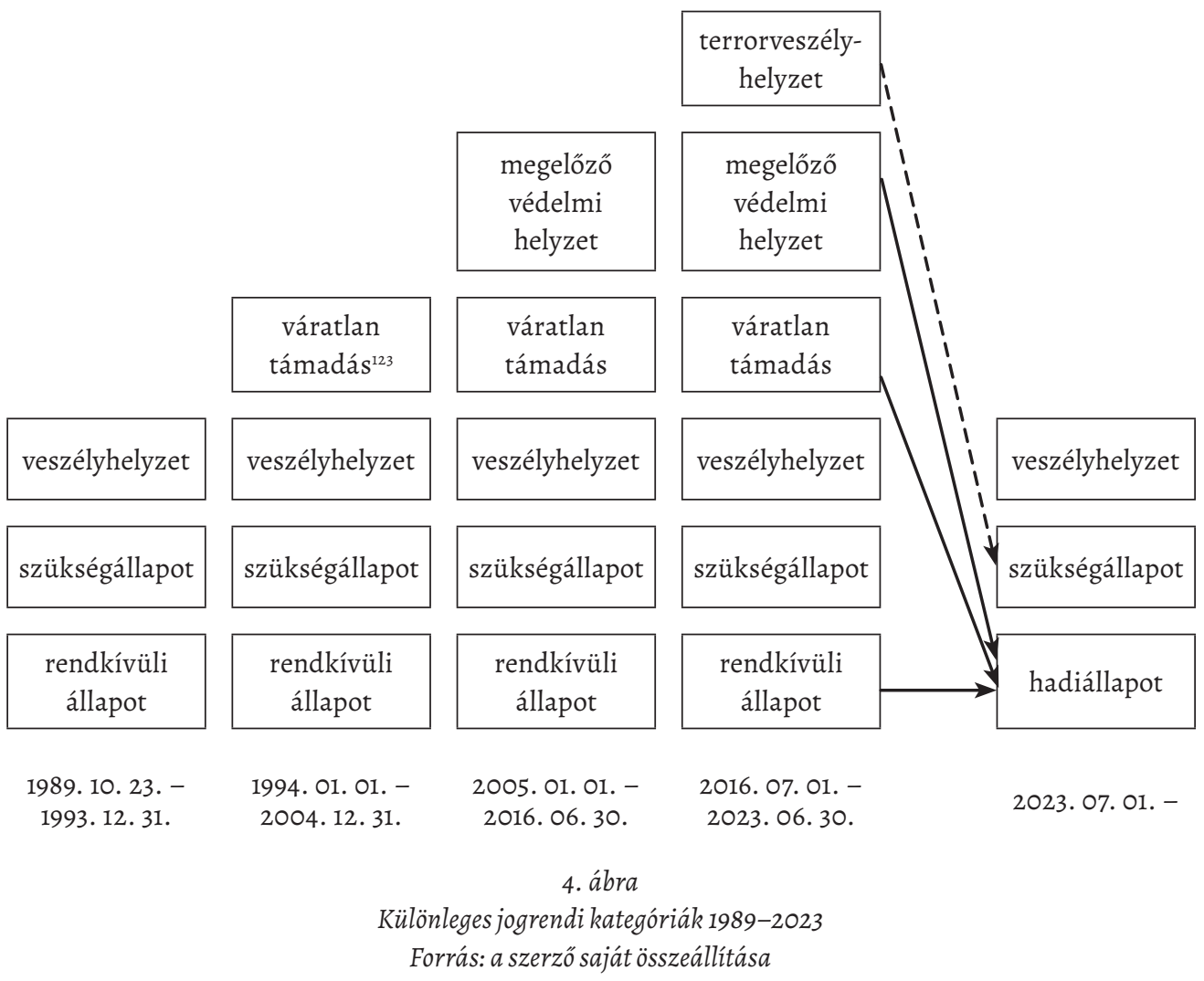

123 Itt ismét felhívjuk a figyelmet arra, hogy az Alkotmány 19/E. \$-a ugyan nem használta a „váratlan támadás” kifejezést, de az egyszerűség kedvéért az ábrában a 2012 előtti szabályozásra is ezt a kifejezést használjuk, ugyanis az Alkotmány 19/E. \$ (1) bekezdése, valamint az Alaptörvény 52. cikk (1) bekezdése lényegét tekintve megegyezik egymással. 
Az 1989-es és a 2023-ra előirányzott szabályozás nemcsak a különleges jogrendi kategóriák számában egyezik meg, hanem abban is, hogy ezek a kategóriák az alapvetố rendeltetésüket tekintve megegyeznek egymással: a rendkívüli állapot/hadiállapot a külső fegyveres (háborús), az állam szuverenitása ellen irányuló támadások elhárítására szolgál; a szükségállapot a belső eredetú veszélyek kezelését teszi lehetôvé, a veszélyhelyzet pedig az ipari-természeti jellegú katasztrófák esetén kerülhet kihirdetésre. A fentiekből azonban az is világossá vált, hogy ez a megfeleltetés egyáltalán nem jelenti azt, hogy a Módosítás tartalmi szempontból is visszatérést jelentene az 1989-es alkotmányszöveghez, hiszen a három kategória - különösen a rendkívüli állapot/hadiállapot - jelentős tartalmi változáson ment át. A fejezetből az is kiderült, hogy nemcsak az egyes tényállások módosultak, hanem az egyes szervek jogkörei is jelentősen átalakultak. Ennek megfelelően a tanulmány összegzése során ezt a két szempontot, vagyis a különleges jogrendi kategóriák számának alakulását, valamint a hatalmi centrumok kérdését járjuk körül.

Ami a különleges jogrendi kategóriák számát jelenti, a Mádl Ferenc Összehasonlító Jogi Intézet 2019-es, 19 külföldi államra kiterjedő kutatása visszaigazolta - és a jelen kötet utolsó fejezete bővebben is tárgyalja - azt a közvélekedést, hogy Magyarország valószínúleg „világrekorder" azzal, hogy alkotmányos szinten hat különböző különleges jogrendet intézményesített. ${ }^{124}$ Amint az előző fejezetben láttuk, a kiinduló három különleges jogrend az újabb és újabb típusú fenyegetések és biztonságpolitikai kihívások nyomán emelkedett hatra. Áttekintve az utólag beiktatott három különleges jogrendet, az alkotmányozó valamennyi esetben arra hivatkozott, hogy az Alkotmány/Alaptörvény aktuális rendelkezései nem alkalmasak egy adott helyzet kezelésére, és így a bevezetni kívánt új különleges jogrend voltaképpen egy „hézagot” töm be. ${ }^{125}$ A különleges jogrendi kategóriák eddigi szaporodásának fényében hogyan értékelhető tehát a Módosítás? Itt érdemes felidézni Tordai Csabának egy közelmúltban született írását: „Mára világosan kiderült, hogy olyan újabb és újabb kihívá-

124 Kádár pedig úgy fogalmaz, hogy nemzetközi összevetésben „az öt különleges jogrendi időszak meglehetősen tagoltnak tekinthetô" (Kádár, 2014, 9. o.).

$125 \mathrm{Az}$ alkotmányozó indokolása így szólt az egyes kategóriák beiktatásakor:

Váratlan támadás: „Nem rendelkezik az Alkotmány azonban idegen hatalom fegyveres támadásának nem minősülő külső fegyveres csoportok (például gerillacsoportok) váratlan betörése, vagy az ország légterének szándékos megsértése, illetve váratlan légitámadás esetén a támadás elhárítása érdekében a fegyveres erők korlátozott mérvú igénybevételéről." (Az Alkotmány módosításáról szóló 1993. évi CVII. törvényhez füzött indokolás).

Megelőző védelmi helyzet: „A minősített időszakok jelenlegi alkotmányi szabályozása hézagos, mivel nem ad lehetőséget az olyan, a megváltozott biztonságpolitikai környezetben esetlegesen felmerülő helyzetek kellő gyorsasággal történő kezelésére, amelyek a rendkívüli állapot szintjét el nem érő biztonsági fenyegetéssel járnak" (A Magyar Köztársaság Alkotmányáról szóló 1949. évi XX. törvény módosításáról szóló 2004. évi CIV. törvényhez füzött általános indokolás 3. pontja).

Terrorveszélyhelyzet: „A kialakult biztonsági környezetre figyelemmel a módosítás az Alaptörvény különleges jogrendi szabályainak kiegészítését szolgálja a terrorizmus új típusú biztonsági kihívásainak megelőzése és kezelése érdekében, [...]." (Magyarország Alaptörvényének hatodik módosításához füzött általános indokolás). 
sokkal szembesülünk időről időre, hogy ismeretelméletileg nagyon nehéz pontos definíciót adni a kihívásokra - mivel pedig maguk a kihívások nem pontosan ismertek előre, lényegében lehetetlen előre pontos tényállással meghatározni, hogy milyen rendkívüli intézkedésekre lehet szükség.” Majd arra figyelmeztetett, hogy „középtávon a minősített időszakokra vonatkozó egész alkotmányos konstrukciónkat - más alkotmányos demokráciák példájához igazodva - újra kell gondolni”. ${ }^{126}$ Kelemen Roland is a túlszabályozottságra hivatkozik, és „fogalmilag kusza alkotmányos helyzet"-ről ír, mihamarabbi felülvizsgálatot sürgetve. ${ }^{127}$ Farkas Ádám a különleges jogrendi kategóriák bővüléséről úgy vélekedik, hogy „[e]z a fajta bővítő megközelítés annak ellenére, hogy esetről esetre elvett a szabályozási rendszer konzisztenciájából és a szabályozás átláthatóságából és ezáltal az alkalmazhatóságából, értelemszerûnek mutatkozott évtizedeken keresztül a sajátos történelmi és biztonsági helyzet miatt”. ${ }^{128}$ Ugyanő egy másik munkájában pedig arra mutat rá, hogy a jogalkotó „az 1989-es rendszerváltozás óta inkább a szabályozással való kontrollálás és állami önkorlátozás módszerét választotta a rugalmas, de megfelelő ellensúlyokkal és intézményi kontrollokkal operáló megoldás helyett. Ennek a szabályozási szemléletmódnak a megnyilatkozása az a végletekig feszített kazuisztika a védelmi és biztonsági szabályozásban [...]". ${ }^{129}$

A Módosítás - ebből a szempontból - annyiban biztosan előrelépést jelent, hogy a tényállások inkluzívabbá váltak (különösen a hadiállapot esetén, és kisebb mértékben a szükséghelyzetnél és a veszélyhelyzetnél). ${ }^{130} \mathrm{Az}$ alkotmányozó által kitűzött átláthatóság egyértelmúen javult azzal, hogy a három katonai típusú különleges jogrend összevonásra került, és az új tényállásokat álláspontunk szerint sikerült úgy megfogalmazni, hogy a jövőben a három korábbi helyzet mindegyike kezelhető legyen az új alaptörvényi szabályozás keretében. (Bizonytalanság - amint fentebb utaltunk rá - egyedül a terrorveszélyhelyzet ,jogutódlása" kapcsán merülhet fel.) Szintén tanulságos Csink Lóránt meglátása, amely szerint „[a] különleges jogrendre okot adó jelenségek változékonysága nem teszi lehetôvé olyan szabályozás kialakítását, amely egyszerre részletes és stabil". ${ }^{131} \mathrm{Az}$, hogy a Módosítás nyomán kevésbé részletessé vált-e a szabályozás, részben értelmezés kérdése (hiszen a részletesség nem kizárólag a kategóriák számától függ), de talán okkal bízhatunk abban, hogy a most kialakított rendszer időtállóbb lesz, mint az 1989-es vagy a 2011-es struktúra. Az új különleges rendi rész kétségtelenül letisztultabb, áttekinthetőbb és logikusabb lett, kevesebb ismétlődő rendelkezéssel. A hadiállapot és a szükségállapot a kezelését tekintve közelebb került egymáshoz, ami elsősorban a Honvédelmi Tanács kiiktatásával és a köztársasági elnök szükségállapoti szerepének jelentős csökkentésével valósult meg.

126 Tordai, 2020.

127 Kelemen, 2017, 68. o.

128 Farkas, 2020a, 352-353. o.

129 Farkas, 2020b, 15. o.

130 Vö.: Farkas Ádám javaslatával (Farkas, 2020a, 369. o.).

131 Csink, 2017, 15. o. 
Egyúttal azonban arra is rá kell mutatni, hogy aligha határozható meg egzakt módon az - alkotmányos szinten szabályozandó - különleges jogrendek „ideális” száma. A több különleges jogrendi kategória mellett elsősorban az az érv szól, hogy minél több a kategória, a kormányzat, - elvileg - annál inkább tudja érvényesíteni az arányosság követelményét, vagyis azt az elvárást, hogy az adott válság kezelésére alkalmas különleges jogrendek közül a lehetô legenyhébb kerüljön bevezetésre. ${ }^{132}$ Ezzel párhuzamosan egy tagoltabb rendszer nagyobb fokú adaptációt tesz lehetővé. ${ }^{133}$ A különleges jogrendi helyzetek nagy száma ugyanakkor értelemszerúen bonyolultabb szabályozással jár együtt, ami - ahogyan fentebb utaltunk rá - szintén kifogás tárgya lehet. Álláspontunk szerint a Módosítás által végrehajtott kategóriacsökkentés sem jelenti okvetlenül az arányosság követelményének sérelmét, hiszen a törvényi szabályozás módosításával megfelelő garanciákat lehet a rendszerbe építeni.

Az elmúlt évtized különleges jogrendi szabályozásának a másik értékelési szempontja a jogkörök elosztása lehet. E helyütt érdemes felidézni Kukorelli István gondolatát: „Visszaemlékezve a háromszögletû́ Nemzeti Kerekasztal tárgyalásaira, igenis ki kell mondanunk, hogy a fegyveres erő tekintetében ott és akkor az operativitás számunkra nem bírt jelentőséggel a hatalommegosztás és az alkotmányos korlátozás követelményei mellett." ${ }^{134}$ Ennek megfelelően a rendszerváltás idejének bizonytalansága, a „túlbiztosításra” való hajlam a különleges jogrendi szabályozáson is rajta hagyta a lenyomatát. Mindez főként a végrehajtó hatalommal (a Kormánnyal) szembeni bizalmatlanságban nyilvánult meg, ${ }^{135}$ hiszen pontosan a két legsúlyosabb különleges jogrend, vagyis a rendkívüli állapot és a szükségállapot szabályozása lett úgy kialakítva, hogy a Kormány látványosan háttérbe szorult. Az „ideiglenes történelmi szituáció indulatai által generált szabályok ${ }^{{ }^{136}}$ aztán évtizedeken át nem módosultak érdemben, bár az kétségtelen, hogy a később felállított különleges jogrendek a Kormány súlyának növekedését és mozgásterének bővülését hozták magukkal. Till Szabolcs ezzel kapcsolatban teszi fel a kérdést, miszerint a különleges jogrendi hatalomgyakorlás hatékonysága szempontjából mennyiben védhetô a döntéshozatali centrumok váltakozása. ${ }^{137}$

132 Vö.: Jakab, 2009, 635. o. Így például a Módosítás nyomán a jövőben akkor is hadiállapotot kell/lehet majd kihirdetni, amikor a jelenlegi helyzet alapján elegendő lenne a megelőző védelmi helyzet bevezetése. Egy esetleges terrortámadás esetén pedig szükségállapotot vagy hadiállapotot kellene kihirdetni, amelyek jóval nagyobb hatalomkoncentrációval és jogkorlátozással járnak, mint a mostani terrorveszélyhelyzet (vö.: Petrétei, 2015, 30. o.).

133 Ezzel kapcsolatban Till - a hazai különleges jogrendi szabályozás összetettségét elemezve - arra mutat rá, hogy „az alapvetően megváltozott biztonságpolitikai környezethez képest a rendszer adaptálhatóságának foka már meghaladja a rendszer elemeinek mennyiségi csökkentéséből önmagából nyerhető előnyöket" (Till, 2017, 73. o.). A szerző egyúttal arra is figyelmeztet, hogy az alkotmányos rendszer kialakítása során a jogi érvelések szerepe nem lehet kizárólagos.

134 Kukorelli István 2015-ös szóbeli közlését idézi: Farkas, 2015, 6. o.

135 Farkas-Kádár, 2016, 305-306. o. Farkas szerint visszatérő probléma, hogy a viták során a mindenkori kormánnyal szembeni bizalmatlanság erősebb, mint a fegyveres védelem kérdéseinek érdemi vonatkozásai (Farkas, 2016b, 174. o.).

136 Farkas, 2016a, 29. o.

137 Till, 2019, 23. sz. jegyzet. 
Amint fentebb kifejtettük, a Módosítás szakít a hatalmi ágak közti határokat összemosó hibrid megoldásokkal, ${ }^{138}$ vagyis a hatalmi centrumok hármasságával (Honvédelmi Tanács köztársasági elnök - Kormány), és - a gyorsasági, az operativitási, valamint a politikai és jogi felelősségi szempontok alapján - mindhárom különleges jogrend idején a Kormányra osztja ki a „válságmenedzser” szerepét.

Zárásként két további szempontot kívánunk hangsúlyozni. Egyrészt a különleges jogrend az alkotmányos rendszerünknek egy egyedülállóan sajátos eleme abból a szempontból, hogy - szerencsére - meglehetősen kevés gyakorlati tapasztalat áll rendelkezésünkre, hiszen a hat meglevő kategóriából egyedül a veszélyhelyzet került már kihirdetésre. Ennek megfelelően talán azt sem túlzás állítani, hogy a fentebb elemzett, a kategóriák „optimális" száma, valamint az egyes szereplők kompetenciája körül forgó viták és dilemmák túlságosan elméleti jellegúek (másik kifejezéssel éve: spekulatívak), hiszen a vizsgálat tárgya egy olyan szabályozás, amely túlnyomórészt eddig csak „papíron” létezett, és így a „Beváltotta-e a Honvédelmi Tanács a hozzá füzött reményeket?" jellegú kérdések nyilvánvalóan értelmetlenek. Másrészt arra is rá kívánunk mutatni, hogy a különleges jogrendről, illetve az ebben bekövetkező változásokról kizárólag az Alaptörvény szövegét alapul véve csak egy korlátozott képet lehet kapni. Jelen kötet kéziratának véglegesítésekor vált ismertté, hogy az Alaptörvény kilencedik módosítása egy átfogó védelmi-biztonsági reform nyitányaként szolgál..$^{139}$

\section{Irodalomjegyzék}

Csink, L. (2017) 'Mikor legyen a jogrend különleges?', Iustum Aequum Salutare, 13(4), 7-16. o. FARKAS, Á. (2015) 'Az állam fegyveres védelmi rendszerének kérdései a kortárs fenyegetések tükrében', Katonai Jogi és Hadijogi Szemle, 3(1), 5-51. o.

138 Farkas, 2020b, 16. o.

139 Jelen kötet már a szakmai lektoráláson is átesett, amikor a Kormány - 2021. május 11-én - az Országgyúlés részére benyújtotta a védelmi és biztonsági tevékenységek összehangolásáról szóló T/16221. sz. törvényjavaslatot. Elérhetô: www.parlament.hu/irom41/16221/16221.pdf (Letöltve: 2021. május 15.). Amint a javaslat általános indokolása a következőképp fogalmaz: „Az Alaptörvény kilencedik módosításának, a 21. századra jellemző új típusú válságok, hibrid fenyegetések hatékony kezelésének és az alapvető jogok minél szélesebb körú védelmének hármas feltételrendszere szükségessé tette a védelmi és biztonsági feladatok és a különleges jogrend idején bevezethető intézkedések jogi szabályozásának megújítását. A jelen törvény e három szempontnak egyszerre kíván eleget tenni. Elfogadása egyedülálló módon járulna hozzá az egyéni és az össztársadalmi biztonságtudat erősítéséhez, a biztonságérzet fokozásához, és végső soron a tényleges biztonság minél nagyobb mértékủ szavatolásához." A javaslat célja többek között az, hogy a különleges jogrend kihirdetését közvetlenül megelőző intézkedések körét, illetve a hadiállapot vagy a szükségállapot kihirdetésének kezdeményezését követôen, továbbá különleges jogrendben bevezethetô intézkedéseket újraszabályozza. 
FARKAS, Á. (2016a) 'Magyarország katonai védelmének polgári evolúciója és alkotmányos alapvonalai' in Farkas, Á., Kádár, P. (szerk.) Magyarország katonai védelmének közjogialapjai. 1. kiadás. Budapest: Zrínyi Kiadó

FARKAS, Á. (2016b) 'Gondolatok a terrorveszélyhelyzetről', Szakmai Szemle, 2016/3, 174-189. o.

FARKAS, Á. (2020a) 'Egy lehetséges narratíva a védelemszabályozási szemléletünk megújításához' in Farkas, Á., Kelemen, R. (szerk.) Szkülla és Kharübdisz között - Tanulmányok a különleges jogrend elméleti és pragmatikus kérdéseirôl, valamint nemzetközi megoldásairól. 1. kiadás. Budapest: Magyar Katonai Jogi és Hadijogi Társaság

FARKAS, Á. (2020b) 'Gondolatok a koronavírus-járvány és a védelmi, biztonsági szabályozás kölcsönhatásairól', Belügyi Szemle, (68)5, 9-22. o.

FARKAS, Á., KÁDÁR, P. (2016) 'A különleges jogrendi szabályozás fejlődése és katonai védelmi vonatkozásai' in Farkas, Á., Kádár, P. (szerk.) Magyarország katonai védelmének közjogi alapjai. 1. kiadás. Budapest: Zrínyi Kiadó

FARKaS, Á., Till Sz. (2016) 'A honvédelmi alkotmány és alkotmányosság alapkérdései Magyarországon' in Farkas Á., Kádár P. (szerk.) Magyarország katonai védelmének közjogi alapjai. 1. kiadás. Budapest: Zrínyi Kiadó

JАKAB, A. (2009) 'Az Országgyưlés akadályoztatása különleges állapotokban' in Jakab, A. (szerk.) Az Alkotmány kommentárja I. 1. kiadás. Budapest: Századvég

JАKAB, A. (2011) Az új Alaptörvény keletkezése és gyakorlati következményei. 1. kiadás. Budapest: HVG-ORAC

JAKAB, A., Till, Sz. (2019): 'A különleges jogrend' in Trócsányi, L., Schanda, B., Csink, L. (szerk.) Bevezetés az alkotmányjogba. Az Alaptörvényés Magyarország alkotmányos intézményei. 6. kiadás. Budapest: HVG-ORAC

KÁDÁR, P. (2014) 'Sarkalatos átalakulások: A kétharmados/sarkalatos törvények változásai a honvédelem területén 2010-2014', MTA Law Working Papers, 2014/36. [Online]. Elérhetô: https://jog.tk.hu/mtalwp/sarkalatos-atalakulasok-a-ketharmadossarkalatos-torvenyekvaltozasai-a-honvedelem-teruleten-2010-2014?download=pdf (Letöltve: 2020 . december 10.)

Kelemen, R. (2017) 'Az Alaptörvény különleges jogrendi rendszerének egyes dogmatikai problémái - kitekintéssel a visegrádi államok alkotmányának kivételes hatalmi szabályaira', Katonai Jogi és Hadijogi Szemle, 2017/1-2, 37-68. o.

Kelemen, R. (2020) 'A mítoszokon túl - önképú kivételes hatalmi szervek a magyar alkotmánytörténetben (A Honvédelmi Bizottmánytól a Honvédelmi Tanácsig)' in Farkas, Á., Kelemen, R. (szerk.) Szkülla és Kharübdisz között - Tanulmányok a különleges jogrend elméleti és pragmatikus kérdéseiről, valamint nemzetközi megoldásairól. 1. kiadás. Budapest: Magyar Katonai Jogi és Hadijogi Társaság

KovÁcs, I. (2015) 'A békeidőszaki válságok fegyveres kezelésének közjogi aspektusa', Katonai Jogi és Hadijogi Szemle, 2015/1, 115-147. o. 
LÁszLó, V. (2018) 'Az Alaptörvény hatálybalépését követő és közvetlenül azt megelőző időszaki különleges jogrend hazai szabályozásának összehasonlító elemzése', Hadtudományi Szemle, 11(4), 366-385. o.

MÉszÁros, G. (2017) ‘,Alkotmány, válságban” - a különleges helyzetek kezelésének dimenziói az Alaptörvény elfogadásától napjainkig', Jura, 2017/2, 118-133. o.

Ősze, Á. (2018) 'Analízis a magyar különleges jogrendi szabályozás hatékonyságáról', Diskurzus, $8(2), 33-44.0$.

Petrétei, J. (2015) A köztársasági elnök rendkívüli állapottal összefüggő feladat- és hatáskörei, Állam-és Jogtudomány, 56(4), 24-44. o.

Bar-Siman-Tov, I., Rozenberg, O., BenoÏt, C., Waismel-Manor, I., Levanon, A. (2021) 'Measuring Legislative Activity during the Covid-19 Pandemic: Introducing the ParlAct and ParlTech Indexes', International Journal of Parliamentary Studies, 1(1), 109-126. o.

SÁGVÁRI, Á. (2016) Különleges jogrenddel a terror ellen - kitekintés az európai gyakorlatra [Online]. Elérhető: https://jog.tk.hu/blog/2016/o2/kulonleges-jogrenddel-a-terror-ellen (Letöltve: 2020. november 10.)

SALGó, L. P. (2020) 'A hazai veszélyhelyzeti jogalkotás a kodifikátor szemével', Fontes Iuris, 6(2), 8-18. o.

SimicsKó, I. (2016) 'A terrorizmus elleni védelem fokozása a különleges jogrendi kategóriák bővítésével', Hadtudomány, 2016/3-4, 100-113. o.

SZENTE, Z. (2020) 'A 2020. március 11-én kihirdetett veszélyhelyzet alkotmányossági problémái', Állam-és Jogtudomány, 61(3), 115-139. o.

SzILVÁsy, Gy. P. (2019) 'A különleges jogrend és a rendeletalkotás', Katonai Jogi és Hadijogi Szemle, 2019/1, 105-131. o.

TiLL, Sz. (2016) 'Alkotmányos változatok migránsokra és terrorra', Katonai Jogi és Hadijogi Szemle, 2016/1-2, 7-63. o.

TiLL, Sz. (2017) 'A különleges jogrendi kategóriarendszer egyszerúsítésének jövőbeli esélyei', Iustum Aequum Salutare, 13(4), 55-75. o.

TiLL, Sz. (2019): 'Különleges jogrend' in Jakab, A., Fekete, B. (szerk.) Internetes Jogtudományi Enciklopédia [Online]. Elérhetô: http://ijoten.hu/szocikk/kulonleges-jogrend (Letöltve: 2020. november 16.)

TORDAI, Cs. (2020) A közjog határai a járványveszély idején [Online]. Elérhető: https:// igyirnankmi.atlatszo.hu/2020/03/16/a-kozjog-hatarai-a-jarvanyveszely-idejen/ (Letöltve: 2020. október 5.) 